\title{
A Literature Review of Empirical Research on the Effects of Digital Games on Learning Styles and Multiple Intelligences
}

\author{
Veljko Aleksić and Mirjana Ivanović ${ }^{2}$ \\ ${ }^{1}$ Faculty of Technical Sciences in Čačak, University of Kragujevac \\ ${ }^{2}$ Faculty of Sciences, University of Novi Sad
}

\section{Abstract}

The paper presents a review of literature resources that studied the effects of digital games on students' learning and intelligence. The research included 5,740 scientific papers from 11 electronic repositories that presented various evidence of multidimensional impact of digital games on students. Categorization and application of multiple qualitative criteria identified 36 representative papers that presented empirical evidence. Various indicators and benchmarks used in papers were analysed, taking into account the methodological limitations. The results confirm the complex relations between digital games andlearning styles and multiple intelligences on which the recommendations and questions for future research are created.

Key words: digital games; learning style; literature review; multiple intelligences.

\section{Introduction}

Digital games started taking primacy in home entertainment industry in the 1970s, thus changing the traditional structures of human play and leisure activities. Technological development, new hardware solutions and faster communication enable continuous enhancement and improvement of computer games that eventually permeate the lives of many generations. Computer and video games have become an indispensable part of children's and adolescents' lives and play an important role in youth culture (Dorman, 1997). Games can now be played anywhere and anytime, as a technology-rich environment is overloaded with laptops, smartphones, mobile and 
home gaming consoles, desktop computers and other digital devices. Internal motivation that young people have towards digital games can be combined with educational content and objectives that Prensky (2003) named digital game-based learning.

The authors' attitude is that the impact of digital games on the lives of generations of students who currently are (or will be) in schools should not be marginalized. On the contrary, playing modern visually/auditorily/kinesthetically-enhanced digital games certainly affects the perceptual, cognitive, affective and psychomotor characteristics of players, thus directly leading to adaptation of students' learning styles and intelligence modalities.

The aim of the research is a systematic review of literary resources of empirical evidence on the effect of digital games on learning styles and multiple intelligences. The analysis can provide useful information to teachers in various areas and levels of education and researchers in the fields of educational psychology, pedagogy, technology-enhanced learning and game-based learning (GBL). The research used the elements of systematic mapping method that includes the search of literary resources in order to assess the scope and quality of published papers (e.g. empirical research) in a particular area of interest (Petersen et al., 2008). Using the above mentionedmethod enabled the aggregation and categorization of papers and the review of area of interest. In order to apply the method successfully, first we defined the research questions. After searching through relevant repositories, the selected papers were analysed and if the defined criteria were met, the information was gathered and afterwards the results were synthesized.

The rest of the paper is organized as follows. The following section presents previous research categorizations on digital games, learning style models and multiple intelligences. We further describe the research methodology, selection criteria development and data analysis framework. Results are then presented, followed bydiscussion and concluding remarks.

\section{Previous Research Categorizations}

Although it is intuitively clear that playing digital games can have numerous positive effects, the analysis of literature presented lack of coherent and systematic research in this domain, which is an obstacle for understanding its impact on learning and creating empirically proven proposals for efficient utilization of this potential. Contemporary education experts pay attention to the possibilities of implementing learning styles and multiple intelligences psychological theories in the classroom, which, in addition to the obvious impact of digital games on students' lives, focused our research on exploring the potential correlation between digital games, learning styles and multiple intelligences.

In order to perform the qualitative analysis, a review of previously established and generally accepted categorizations of digital games, learning styles and multiple intelligences is created and presented further. 


\section{Digital Games}

Digital games have two unique characteristics: transmediality and enframing. Transmediality is reflected in the phenomenon that games can be played through various media (Juul, 2011). Development of technology accounts for the fact that modern digital games are narrowing the gap between the virtual and the real world so that players are increasingly being placed in a position to physically interact with virtual characters and environments. The term enframing is related to the digital nature of computer games. According to Heidegger and Lovitt (1977), the influence of modern technology on human play is the enframing of the features and characteristics of the virtual world created by a game designer.

Initial investigations of the impact that digital games have on students mostly dealt with the psychological and emotional effects, often through analyses of the negative aspects of playing and the relation of "violent" games and aggressive behaviour. It is not difficult to find a relationship between playing video games and violent behaviour, if desired. Griffiths and Hunt (1995) concluded that $98.7 \%$ of adolescents play video games to some extent, with the fact that boys play more, and more often choose a violent game. In their meta-analysis, Anderson and Bushman (2001) suggest that playing violent digital games arouses aggressive thoughts, behaviour, and physiological arousal. Despite the intensive debate amongst experts, research of the relationship between violent games and aggressive behaviour has produced mixed results. For example, Anderson and Dill (2000) argued that they experimentally proved the link between games and aggressive behaviour, but when Ferguson et al. (2008) attempted to replicate the findings using a standardized procedure in their study, they failed. Moreover, the only correlation that they could prove was related to the connection of domestic violence with violent games and aggressive behaviour. In addition to aggression, researchers have studied the problems and inability to regulate the amount of time students spend playing (Ogletree \& Drake, 2007), and relation between playing digital games and social isolation (Griffiths \& Davies, 2002).

Despite the initial negative connotation, the interest in studying the positive effects of playing computer games was soon developed. Ferguson (2007) examined positive and negative effects of playing digital games in his meta-analysis and concluded that playing is related to improving visual/spatial skills. However, the question of why games generated this effect remained for future research.

The obvious motivation factor and the assumption that video game players can develop useful skills induced De Freitas (2006) to observe computer games as a new and attractive learning method. Using educational computer games can be effective only if elements such as goals, competitions, challenges and fantasy positively influence the motivation to learn. Motivation is related to the initiation, intensity and duration of certain behaviour. It can be observed as the dyad of intrinsic (developed from the students' interest in acquiring knowledge or mastering the skill) and extrinsic (based on the goal or grade achievement or the avoidance of penalty) motivation. 
Although at first glance attractive, using games in the classroom environment does not always motivate students. For example, if the difficulty level is too high, the student's frustration increases, which reduces the level of confidence (Seery et al., 2004). Successful playing involves the transition to a higher level and mastering the new competences, resulting in a better player performance. In addition, a sense of enjoyment in learning through games reduces anxiety.

Digital games can generally be integrated into the educational process in three ways (Sung et al., 2011; Wang \& Wu, 2009):

- Using games instead of traditional exercises to motivate students to devote extra effort in the tasks realization, which presents the teacher with the opportunity to monitor student performance in real time (Foss \& Eikaas, 2006; Sindre et al., 2009);

- Playing while learning in the classroom to improve motivation and student engagement (Wang et al., 2007, 2008);

- Modifying or creating digital games by students in order to acquire skills in the field of computer science (El-Nasr \& Smith, 2006). This process is called game development-based learning, and is used with the aim of utilization of students' enthusiasm to play.

After an initial interest in the use of commercial-off-the-shelf (COTS) games in the classroom, the focus shifted towards learning based on games specifically developed for education (e.g. GBL). Rodrigues and Carvalho (2013) emphasized the strategies of using popular commercial games (e.g. Angry Birds in the course of physics) but did not present the implementation of the analysed concepts. Bopp (2007) stated that the narration in games can motivate students positively. It is useful in the learning environment and provides an opportunity for reflection, evaluation, illustration and example provision (Kelleher et al., 2007; Malone, 1981). Contemporary educational theories support the concept of active, experiential, problem learning, combined with synchronous feedback (Boyle et al., 2011), which is easily accomplished using digital games. Experts are also interested in research on "serious games" (SG) designed to influence the behaviour and attitudes, mainly in education, health care, marketing etc.

Research has mainly focused on the diverse manner of application of digital games in the learning process, usually in the cognitive domain. Authors' stance is that the evaluation of any learning environment (formal, non-formal or informal) must take into account the qualitative aspects, such as the influence on students' attitudes, experiences, learning styles and intelligences. The basic principle of a meaningful education is that all students can learn if given proper personalized conditions (Robinson, 2009).Ke (2009) states that the literature on computer games in learning and teaching is incoherent although it is obvious that gaming accounts fora multitude of positive outcomes. A lack of organization is considered to be an obstacle in understanding effects of digital games, development of more effective games, and creation of instruction for the "best" use of games in education. 
Various digital games categorizations have been proposed by many researchers. When creating the model, the digital game must be first set up in the appropriate framework, bearing in mind if it was developed for entertainment, learning or as a serious game. COTS games have been primarily developed for entertainment and recreation, while learning and behavioural adaptation are the basic goals of GBL and SG, as presented in Figure 1. Corti (2006) states that the terms GBL and SG are sometimes considered to be synonymous, although SG are developed for far wider use in the areas of business, industry, marketing, health care, etc., not only education (Sawyer \& Smith, 2008).

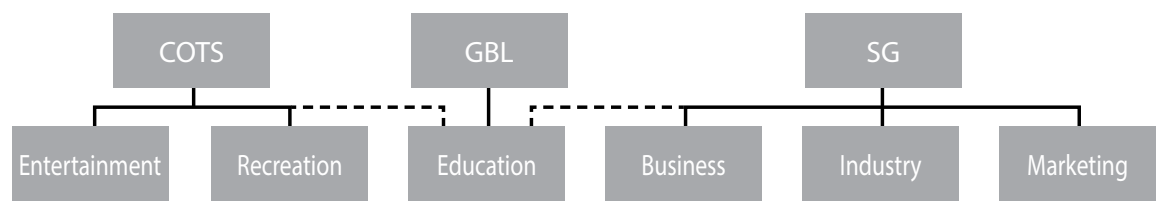

Figure 1 Digital games types and planned purpose

Computer game genre is identified within the established entertaining games classification, which provides a useful way of identifying similarities between the games. Although there is no generally accepted game genre taxonomy, Herz (1997) created one of the first systematizations similar to that used in the video game industry:

- Action (based on the reaction, typical shooter and platform games);

- Adventures (solving logic problems in order to progress through the virtual world);

- Fighting games;

- Puzzle (e.g. Tetris);

- Role-playing games (RPG);

- Simulation;

- Sport;

- Strategy.

Although these genres are relevant to COTS games, the systematization implementation is unclear in GBL and SG. Modern technologies, such as mobile games, online games, virtual worlds and alternate reality games expanded the ways of playing, the media and the platforms on which the game is played. This requires the adaptation of Herz's systematization and its extension with animated tutorials, online games, mobile games, virtual reality, N/A.

In addition to the categorization, it is useful to contemplate on how the dimensions in which games influence students can be classified. Probably the most important classification is the one based on a relationship between digital gameplay and learning outcomes and the acquired behaviour. The fact that digital games are extremely popular speak in favour of the opinion that positive emotional experiences can be observed as the desired gaming outcome, even though the understanding of the sense of "enjoyment" in playing games has not been sufficiently investigated. 
Digital games are increasingly being studied in the context of learning, so several models have been developed to identify the different learning outcomes achieved by playing:

- Garris et al. (2002) created a distinction between gaining skills (psychomotor and technical), and cognitive (declarative, procedural and strategic knowledge) and affective (attitudes, beliefs and emotional influence) achievements;

- O'Neil et al. (2005) identified five groups of cognitive requirements that are met while playing: understanding the content, problem solving, collaboration, communication and self-regulation;

- Wouters et al. (2009) proposed a model based on four types of accomplishments that can be achieved by playing: gaining cognitive knowledge and skills, psychomotor and communication skills, and positive attitudes.

As contemporary understanding of effective learning takes into account the fact that a multitude of variables influence academic success, Connolly et al. (2008) proposed a broader model of educational games evaluation that, besides monitoring player performance, included motivational variables (interest and commitment) and personal perception and attitudes.

The authors' stance is that the analysis of digital games effects on students must embrace affective/motivational factors and influence on the learning style or multiple intelligence profile, besides the evaluation of its influence on the players' knowledge and skills.

\section{Learning Style Models}

The learning style concept is based on the idea that students have various preferences towards learning, and approach it differently. The specific instructional environment may not suit all students alike (Reigeluth, 1996). For example, some students prefer active group discussion, while others want to read on their own. These differences are generally recognized as learning styles and researchers are constantly identifying, classifying and articulating them in order to achieve positive impact on the process of learning. Various learning styles can be observed as a consequence of the different ways of information processing (Felder, 1996), as students learn more efficiently if instruction is in accordance with their individual learning style (Rasmussen \& Davidson-Shivers, 1998).

The study of various learning styles confirmed that students learn in many ways (Murphy, 1992; Spalter et al., 2000). This position is critical in engaging all students, especially underachievers and those without continuous formal education. Chorianopoulos et al. (2014) stated that playing video games provided students with "mental exercise" and that the structure of activities integrated in video games developed a multitude of cognitive abilities, which further emphasizes the need to design meaningful and playful applications. Moreover, the appearance of SG has enabled wider acceptance of student-centred learning model and other adaptations of educational practices. 
Park et al. (2012) stated that Piaget (1976) and Kolb's (2014) theory described the learning process through four stages of cognitive development and learning mechanisms necessary for a complete understanding and application of the concepts. Both support the experiential learning concept, and observe students as active explorers of knowledge. According to Sharda (2007), a learning style is a consistent model of information acquisition and assimilation by students in order to gain knowledge. As learning styles are in close correlation with personality types, a multitude of models for styles description and classification were developed over the years, and some of the widely recognized were proposed by Jung (2014), Myers and Myers (2010), and Kolb et al. (2014). Although there are many models, probably the most frequently cited ones are these:

- Dunn and Dunn (1978) learning style model that describes five components of stimuli and elements that influence the learning process:

o environmental (sound, light, temperature, design),

o emotional (motivation, responsibility, task persistence, structure),

o sociological (self, pair, peers, team, adult, varied),

o physiological (perceptual, intake, mobility, time of day), and

o psychological (analytic - global, reflective - impulsive);

- Felder and Silverman's (1988) theory that classifies students on four scales:

$o$ active (discussing, applying, explaining) / reflective (thinking quietly),

o sensing (learning facts) / intuitive (discovering possibilities and relationships), o visual (see pictures, diagrams, flow charts, etc.) / verbal (written and spoken words), and

o sequential (gain understanding in linear steps) / global (learn in large jumps);

- Kolb's (2014) theory that proposes four learning styles based on the levels in which students engage:

o diverging (feeling and watching),

$o$ assimilating (thinking and watching),

o converging (thinking and doing), and

$o$ accommodating (feeling and doing);

- Honey and Mumford's (2000) model which classifies students in four styles:

o reflector (observes and reflects),

o theorist (understands underlying reasons, concepts and relationships),

o pragmatist (likes to try things to see if they work), and

$o$ activist (prefers doing and experiencing); and

- Fleming's (2006) VARK model which identifies four learning styles:

o visual (prefers the use of diagrams, charts and symbols),

$o$ auditory (best understands new content through listening and speaking),

o read \& write (learns best through words),

o vkinesthetic (hands-on learners, tactile activities).

Differentiation of learning styles has been confirmed by many studies, leading towards the need to adopt various approaches to educational process (Chwif \& 
Barretto, 2003). It should be emphasized that the learning styles of young "virtual" generations vary from the previous ones, as they are far more oriented towards the visually presented information, interaction and problem solving (Pasin \& Giroux, 2011; Proserpio \& Gioia, 2007).

Cognitive assessment can be performed in various ways. Identification and evaluation of learning styles have been explored for decades, based on various models and inventories (Weaver et al., 2013). Psychometrics is a scientific field concerned with the creation and evaluation of valid psychological tests (Hoffman, 2002). Researchers emphasized three basic problems in instrument development: imprecision of learning style definition, weaknesses in the reliability and validity, and difficult identification of the relevant instruction environment characteristics. In the context of digital games, the effective strategy for most learning styles is practical and active learning (Bailey \& Forbes, 2005; Qiu \& Riesbeck, 2004; Roschelle et al., 2007).

It should be noted that learning style theories have been challenged by a small group of researchers. For example, Felder (1993) concluded that visual images were an adequate learning aid to students who preferred a visual learning style. However, Grissom et al. (2003) challenged this model, as they did not prove the correlation between responses to visual stimuli and the identified visual learning style, although they intuitively anticipate it, and note that some alternative appropriate models of learning style identification would probably present more favourable results.

It is important to emphasize that learning styles do not represent a static trait. Students can prefer different learning styles depending on the context and motivation.

\section{Theory of Multiple Intelligences}

Gardner's theory of multiple intelligences (Gardner, 1993) is considered as one of the key discoveries of educational psychology of the late 20th century. Gardner defines intelligence as the person's ability to successfully respond to the demands of the new situation or event and their capacity to learn from previous experiences. The theory of multiple intelligences (MI) is based on evolutionary biology, neuroscience, psychometrics and psychological research.

Thanks to its individualized approach and practical application in teaching, the theory of multiple intelligences has prompted enthusiasm in various educational circles. Researchers quickly recognized the advantages of identifying intelligences in multiple areas unlike the previously unified intelligence quotient (IQ).

The profiles of intelligences and their basic description defined by the MI theory are (Gardner, 1993):

- Verbal/linguistic - represents the primary mean of communication amongst humans. It is reflected in symbolic thinking, language, reading, writing;

- Logical/mathematical - is used for data processing, pattern recognition, working with numbers, geometric shapes; 
- Visual/spatial - navigation, map making, visual arts, architecture, perspective;

- Bodily/kinesthetic - reflects the precise self-body motion control, non-verbal emotion expression, dance, fine hand-eye coordination;

- Musical/rhythmic - recognition and use of rhythmic and tonal patterns, recognition of sound, speech and musical instruments. It is used to interpret and create music;

- Natural - recognizing patterns in nature, classification of objects and types of wildlife;

- Interpersonal - the possibility of cooperation in small groups, communication with other people, a person's ability to recognize other people's intentions, moods, motivation, non-verbal signs;

- Intrapersonal - recognizing one's own abilities, capacities, feelings andemotional reactions, self-reflection, and intuition.

The evidence of existence of a theoretical ninth (existential) intelligence has not been clearly established (Moran et al., 2006), so it will not be considered.

The MI theory facilitates the understanding of the students' mindset and helps us exploit it better with the aim of increasing learning efficiency, understand and respect individual differences among students, but also it serves as a diagnostic tool in directing further education (Booth \& O’Brien, 2008). Computers, digital technology and games in the classroom create a natural environment for the practical implementation of the MI theory and adaptation of the teaching practice towards student-centred learning. Software developments and the era of the digital media have made the operationalization of individualized learning much more practical, and computers and digital games integration in the learning environment have created a potential to further enhance teaching by activating multiple intelligences.

Multiple intelligences profile can estimate students' personal intellectual dispositions. Difficulties in measuring the attitudes, skills and character are rooted in a complicated procedure of quantifying these qualities in order to carry out the data analysis. Assessment tools for profiling multiple intelligences have been developed by several researchers (Armstrong, 2000; Kagan \& Kagan, 1998; Silver et al., 2000). Intelligences can be assessed by portfolios, written reports, tests, self-evaluation, project performance, etc. However, although traditional pen-and-paper tests apparently intensify verbal/linguistic and logical/mathematical intelligences, a general research standpoint is that it is not currently possible to develop a unique alternative method for multiple intelligences evaluation. The educational community highlights Shearer's (2004) Multiple Intelligences Developmental Assessment Scales (MIDAS) as the instrument of the highest quality. Developed over the last two decades, it has constantly been refined by a combination of rational and empirical methodologies, and has proved to be valid and very reliable. MIDAS assesses MI performance through selfidentification of individual capabilities and aspirations. 


\section{Research on the Effects of Digital Games on Learning Styles and Multiple Intelligences}

A literature review was designed with the aim to collect, classify and analyse the results of empirical research focused on the relationship between digital games and learning styles or multiple intelligences, thus to empirically confirm the optimism on potential specific applications of digital games in the educational process. The analysis is based on the methodology and the results of previous similar research in the area of SG, GBL and COTS games application in education (Connolly et al., 2008, 2012; Kirriemuir \& McFarlane, 2004; Wu \& Wang, 2012). For the purpose of the literature review, a multidimensional framework for the digital games categorization and application hasbeen developed.

\section{Methodology}

The analysis of previous empirical research was carried out on a number of specific steps that were modelled on the systematic review methodology (Higgins \& Green, 2008; Khan et al., 2001):

- review protocol development,

- data collection,

- selection criteria identification,

- data selection,

- data analysis (categorization and qualitative analysis),

- results synthesis,

- evaluation/conclusion.

\section{Protocol Development and Data Collection}

A protocol for literature review was developed in accordance with the guidelines and procedures of the Campbell Systematic Reviews (Petticrew \& Roberts, 2008) and Cochrane Handbook for Systematic Reviews and Interventions (Higgins \& Green, 2008). Considering these procedures, we determined the aim of the research, search and data collection strategies, selection criteria and methods of analysis.

In order to implement the research, data collection was completed in July 2015 . The analysis was carried out on a sample of papers gathered from 11 available electronic databases relevant to the fields of education, information technology, computer science, and social sciences: ACM Digital Library (http://dl.acm.org/), Cambridge Journals Online (http://journals.cambridge.org/), Elsevier/ScienceDirect (http:// www.sciencedirect.com/), ERIC (http://eric.ed.gov/), Oxford Journals (http://www. oxfordjournals.org/en/), Emerald (http://www.emeraldinsight.com/), IEEE Xplore Digital Library (http://ieexplore.ieee.org/Xplore/), Wiley Online Library (http:// onlinelibrary.wiley.com/), Springer/Kluwer (http://link.springer.com/), Sage Journals (http://online.sagepub.com/), and Ingenta Connect (http://www.ingentaconnect.com/).

The repository (e-database) selection criteria were restricted by the availability of full-text paper access to the authors. 


\section{Criteria Identification and Paper Selection}

In line with the area of interest, we used the search terms: "game" "learning style" and "multiple intelligences". Query results were further filtered with the aim of focusing on the effects of digital games in education, as we took into account papers which mentioned only the following terms: "digital", "video", "game-based", "serious",

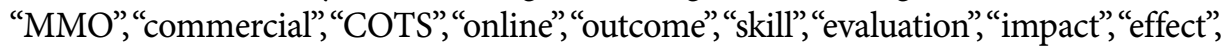
"education", "behaviour", "attitude", "engagement", "motivation" and "affect".

Terms for digital (video, serious, commercial, online, education, etc.) games effects on learning styles or multiple intelligences were derived from consideration of terms used for outcomes, impact, and effects as well as skills, behaviour, motivation, attitudes and affect:

(game OR "learning style" OR "multiple intelligences") AND (digital OR video OR serious OR commercial OR online OR education OR MMO OR COTS) AND ("gamebased" OR outcome OR skill OR evaluation OR impact OR effect OR behaviour OR attitude OR engagement OR motivation OR affect).

To consider a paper in the analysis, a certain qualitative criteria had to be fulfilled:

- existence of research on the effect of digital games on learning styles or multiple intelligences;

- published in the last 15 years (from January 2000 to June 2015);

- can be downloaded as full-text and includes an abstract;

- it is written in the English language.

Using these criteria, a total of 5,740 papers were identified and selected for further analysis.

\section{Data Analysis}

In order to ensure the quality of criteria application on the selected sample, a typology was established according to the scheme which has been recognized, accepted and repeatedly successfully applied (Dempsey et al., 1993, 1996; Wu \& Wang, 2012). The typology was adapted in order to synthesize the results and further discuss the relationships between digital games and learning styles or intelligences; hence we defined five types of papers:

- research (systematic empirical examination of digital games effects aimed at explaining, predicting, or controlling certain phenomena and variables related to learning styles or multiple intelligences);

- theoretical presentation (explanation of basic concepts, aspects, or indirect outcomes of using digital games in education);

- review paper (synthesis of articles by defined methodology that generally or specifically examined the relationships between digital games and learning styles or multiple intelligences);

- discussion (experience or opinion essay with no empirical evidence);

- development (design or development of digital games or projects in correlation to learning styles or intelligences). 
The authors first assessed the retrieved titles and abstracts according to relevance. The selected papers were further independently evaluated in order to reduce bias. The categorization of the selected papers was carried out on several criteria:

- Type of article: research, theoretical presentation, review paper, discussion, development;

- The computer game primary paradigm: commercial (e.g. COTS), educational (e.g. $\mathrm{GBL}$ ), applied (e.g. SG), massively multiplayer online (MMO);

- Genre (according to the extended Herz's systematization);

- Field of application: in general, science, engineering, mathematics, language, health, history;

- Platform: PC, gaming console, mobile device, online;

- Relation to learning style or multiple intelligences;

- The form of empirical research: descriptive (survey, case-study), correlation (casecontrol study), quasi-experimental, experimental, literature review, meta-analysis;

- Empirical sample size;

- Empirical data collection and analysis: research objectives, methodology, results;

- Citation.

In order to additionally assess the papers, a qualitative analysis of four defined categories was performed, resulting in a grade range 1-10. Partial grade categories are:

- Type of research:

o 1 - descriptive (theory, discussion, development)

o 2 - correlation (review paper)

o 3 - quasi-experimental

o 4 - experimental

o 5 - literature review, meta-analysis

- Adequate methodology and analysis ( 0 - no, 1 - yes)

- Sample quality - representativeness ( 0 - low, 1 - medium, 2 - high)

- Relevancy to this research (0 - low, 1 - medium, 2 - high).

As one of the authors had the methodological expertise in writingliterature reviews, in just a few cases of unclear/problematic estimate two highly referenced educational experts in the field of educational psychology were additionally consulted.

\section{Results}

The tendency of the number of papers published by the year and repository is presented in Figure 2. The representative structure is the result of the applied qualitative criteria. The obvious increased interest of researchers over the last ten years makes this issue topical. One of the reasons for this tendency is certainly the influx of students who are growing up in a culture permeated by digital games in which the focus has shifted from the potentially negative effects to the positive aspects, such as social integration, various skills improvement, and intensification of using games in education. Also, one should not forget that younger teachers grew up in the similar 
cultural milieu, so the use of digital games in the learning process comes naturally to them. The authors' stance is that this phenomenon should be interpreted as another sign of the impact that digital games have on students' learning styles, intelligences, and indirectly the teaching practice.

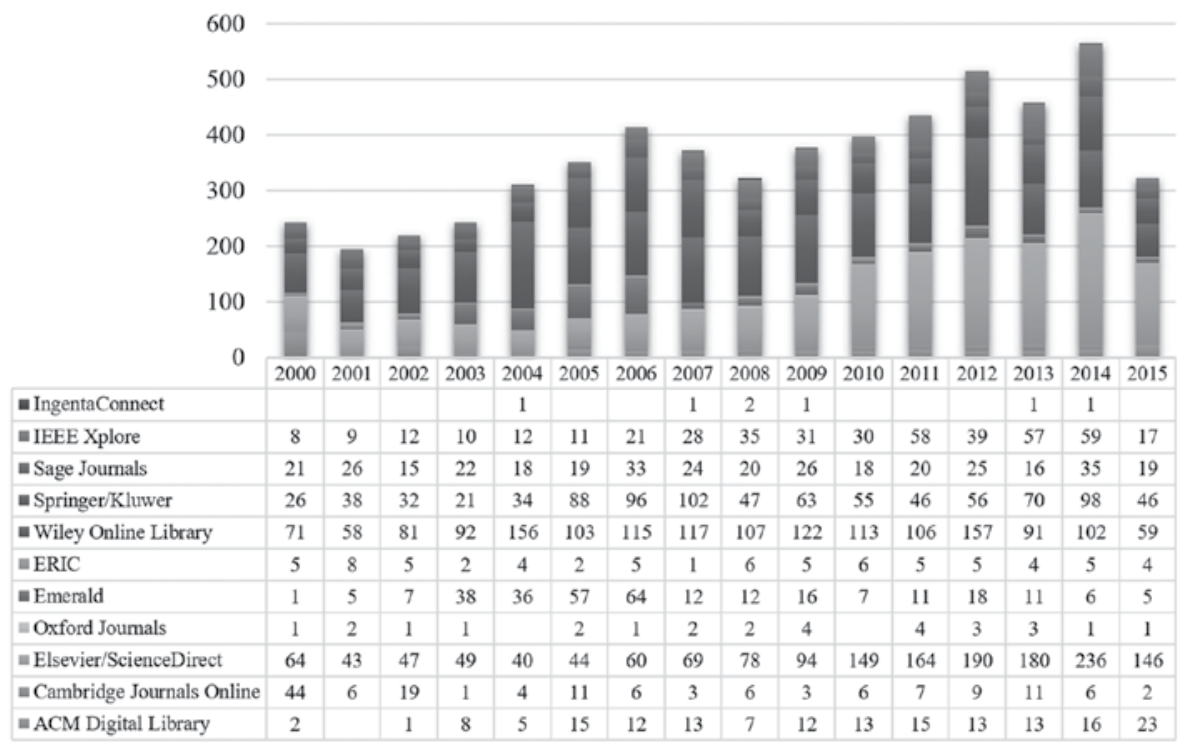

Figure 2 Tendency of the number of papers selected for the analysis by the year and repository

An overview of the number of papers selected from the defined repositories is presented in Table 1 . As can be observed, $74 \%$ of the sample was originally located in three repositories: Elsevier/ScienceDirect $(\mathrm{N}=1653)$, Wiley Online Library $(\mathrm{N}=1650)$ and Springer/Kluwer ( $\mathrm{N}=918$ ).

A total of 5,740 papers were selected querying the available 11 repositories in line with the defined criteria. Fox example, a relatively common case of rejection were the papers related to the game theory and the economics.

Categorization and the defined quality criteria application reduced the sample to 36 papers. The rejected papers often did not explore the effects of digital, but physical games and activities. Posters, presentations, and tutorials were also rejected, as they did not provide detailed description of the research, which made the evaluation of methodology or results practically impossible.

Each paper that met the specific quality criteria was additionally evaluated in the qualitative analysis. The papers were initially grouped in five defined types: research $(\mathrm{N}=19)$, theoretical presentation $(\mathrm{N}=4)$, review paper $(\mathrm{N}=2)$, discussion $(\mathrm{N}=4)$, and development $(\mathrm{N}=7)$. In analogy to the results of similar analyses (Hays, 2005), the number of papers in the review, discussion and theoretical presentation categories was small, which can be explained by the fact that the application of digital games in education is a relatively new domain of educational practice. 
Table 1

The number of papers by repositories

\begin{tabular}{lcc}
\hline \multicolumn{1}{c}{ Repository } & $\begin{array}{c}\text { Papers selected } \\
\text { for the analysis }\end{array}$ & $\begin{array}{c}\text { Papers that met the } \\
\text { quality criteria }\end{array}$ \\
\hline ACM Digital Library & 168 & 4 \\
Cambridge Journals Online & 144 & 1 \\
Elsevier/ScienceDirect & 1,653 & 11 \\
Oxford Journals & 28 & 0 \\
Emerald & 306 & 0 \\
ERIC & 72 & 5 \\
Wiley Online Library & 1,650 & 7 \\
Springer/Kluwer & 918 & 1 \\
Sage Journals & 357 & 3 \\
IngentaConnect & 7 & 0 \\
IEEE Xplore & 437 & 4 \\
Total & $\mathbf{5 , 7 4 0}$ & $\mathbf{3 6}$ \\
\hline
\end{tabular}

The qualitative analysis grades distribution is presented in Table 2 and Figure 3. Mean grade value for the selected 36 papers is 5.44 (standard deviation=2.466), while the modal rating is 5 , which indicates that the papers graded 5 or more are considered methodologically relevant and in this case provide "stronger" evidence.

Table 2

The number of papers by grades

\begin{tabular}{ccccc}
\hline Valid & & Frequency & Valid Percent & Cumulative Percent \\
\hline & 1 & 2 & 5.6 & 5.6 \\
& 2 & 3 & 8.3 & 13.9 \\
& 3 & 4 & 11.1 & 25.0 \\
& 4 & 4 & 11.1 & 36.1 \\
& 5 & 6 & 16.7 & 52.8 \\
& 6 & 3 & 8.3 & 61.1 \\
& 7 & 5 & 13.9 & 75.0 \\
& 8 & 5 & 13.9 & 88.9 \\
& 9 & 3 & 8.3 & 97.2 \\
& 10 & 1 & 2.8 & 100 \\
Total & & 36 & 100 & \\
\hline
\end{tabular}

The results of the structure analysis of representative sample are presented in Table 3. Most of the papers presented research on educational games implementation (66.7\%), SG application was explored in five papers (13.9\%), COTS games were in the focus of four papers (11.1\%), while the MMO application was analysed in three papers. Papers concerning the game genre, puzzles, simulations, and RPGs were mostly represented (58.3\%). Educational games were most often puzzles (25\%), following RPGs (20.8\%) and simulations (12.5\%). 


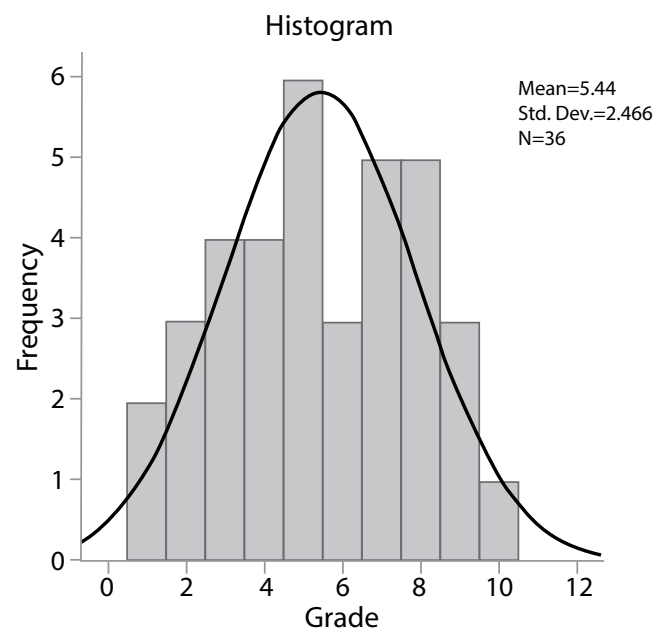

Figure 3. The histogram of paper grades

Table 3

Structure of the research by the game genre (papers graded 5 or more in parentheses)

\begin{tabular}{|c|c|c|c|c|c|c|c|c|c|c|c|c|}
\hline \multirow[b]{2}{*}{ Research } & \multicolumn{7}{|c|}{ Game genre } & \multicolumn{4}{|c|}{ Paradigm } & \multirow[b]{2}{*}{ Total } \\
\hline & 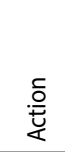 & 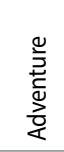 & $\frac{\frac{O}{N}}{\frac{N}{2}}$ & 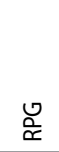 & 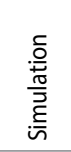 & 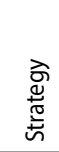 & $\stackrel{\frac{1}{z}}{z}$ & 气̆ & 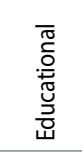 & 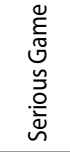 & $\sum_{\Sigma}^{\circ}$ & \\
\hline Survey & $0(0)$ & $0(0)$ & $1(0)$ & $0(0)$ & $1(1)$ & $0(0)$ & $1(1)$ & $0(0)$ & $2(2)$ & $1(0)$ & $0(0)$ & $3(2)$ \\
\hline Case-study & $1(1)$ & $1(1)$ & $1(1)$ & $1(1)$ & $0(0)$ & $2(0)$ & $2(2)$ & $2(2)$ & $6(4)$ & $0(0)$ & $0(0)$ & $8(6)$ \\
\hline Case-control study & $0(0)$ & $0(0)$ & $0(0)$ & $0(0)$ & $1(1)$ & $0(0)$ & $0(0)$ & $0(0)$ & $1(1)$ & $0(0)$ & $0(0)$ & $1(1)$ \\
\hline Quasi-experimental & $0(0)$ & $0(0)$ & $2(2)$ & $2(1)$ & $0(0)$ & $0(0)$ & $0(0)$ & $0(0)$ & $3(3)$ & $0(0)$ & $1(0)$ & $4(3)$ \\
\hline Experimental & $0(0)$ & $1(1)$ & $1(1)$ & $3(3)$ & $3(3)$ & $0(0)$ & $1(0)$ & $0(0)$ & $7(6)$ & $1(1)$ & $1(1)$ & $9(8)$ \\
\hline Literature Review & $0(0)$ & $0(0)$ & $1(1)$ & $0(0)$ & $0(0)$ & $0(0)$ & $1(1)$ & $1(1)$ & $1(1)$ & $0(0)$ & $0(0)$ & $2(2)$ \\
\hline Meta-analysis & $0(0)$ & $0(0)$ & $0(0)$ & $0(0)$ & $0(0)$ & $0(0)$ & $1(1)$ & $0(0)$ & $1(1)$ & $0(0)$ & $0(0)$ & $1(1)$ \\
\hline$N / A$ & $0(0)$ & $0(0)$ & $1(0)$ & $0(0)$ & $3(0)$ & $0(0)$ & $4(0)$ & $1(0)$ & $3(0)$ & $3(0)$ & $1(0)$ & $8(0)$ \\
\hline Total & $1(1)$ & $2(2)$ & $7(5)$ & $6(5)$ & $8(5)$ & $2(0)$ & $10(5)$ & $4(3)$ & $24(18)$ & $5(1)$ & $3(1)$ & $36(23)$ \\
\hline
\end{tabular}

The researchers mainly implemented games on the PC platform (80.6\%) for general/ universal purposes (58.3\%), often for simulation and puzzle genres (in total $47.1 \%$ ). The papers most often explored learning styles, mainly for general application (55.2\%), while $13.9 \%$ of papers investigated the effects of games on multiple intelligences. The structure of games application in the selected papers is presented in Table 4 .

The main objective of this paper is to review and analyse research on the effects of digital games on learning styles and multiple intelligence. The number of papers dealing with this issue which meet rigorous criteria is obviously small. The experimental and case study research methods were most commonly used (50\%). A large number of papers on effects of digital games that did not qualify for the analysis were focused on motivation, cognitive achievements and outcomes. 
Table 4

Game genre and application (papers graded 5 or more in parentheses)

\begin{tabular}{|c|c|c|c|c|c|c|c|c|c|c|c|}
\hline \multirow[b]{2}{*}{ Game genre } & \multicolumn{7}{|c|}{ Application } & \multicolumn{3}{|c|}{ Model } & \multirow[b]{2}{*}{ Total } \\
\hline & $\begin{array}{l}\overline{\widetilde{\pi}} \\
\overline{\mathbb{U}} \\
\overline{\mathbb{N}}\end{array}$ & 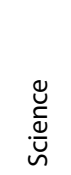 & 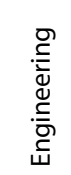 & 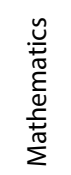 & 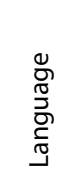 & 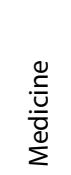 & 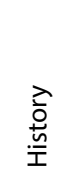 & $\overleftarrow{z}$ & 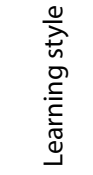 & 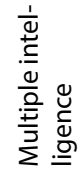 & \\
\hline Action & $1(1)$ & $0(0)$ & $0(0)$ & $0(0)$ & $0(0)$ & $0(0)$ & $0(0)$ & $0(0)$ & $0(0)$ & $1(1)$ & $1(1)$ \\
\hline Adventure & $1(1)$ & $0(0)$ & $1(1)$ & $0(0)$ & $0(0)$ & $0(0)$ & $0(0)$ & $0(0)$ & $2(2)$ & $0(0)$ & $2(2)$ \\
\hline Puzzle & $2(1)$ & $1(1)$ & $0(0)$ & $0(0)$ & $3(2)$ & $1(1)$ & $0(0)$ & $0(0)$ & $5(3)$ & $2(2)$ & $7(5)$ \\
\hline RPG & $2(1)$ & $4(4)$ & $0(0)$ & $0(0)$ & $0(0)$ & $0(0)$ & $0(0)$ & $0(0)$ & $6(5)$ & $0(0)$ & $5(5)$ \\
\hline Simulation & $3(1)$ & $0(0)$ & $1(1)$ & $1(0)$ & $0(0)$ & $1(1)$ & $2(2)$ & $1(1)$ & $6(4)$ & $1(0)$ & $8(5)$ \\
\hline Strategy & $2(0)$ & $0(0)$ & $0(0)$ & $0(0)$ & $0(0)$ & $0(0)$ & $0(0)$ & $0(0)$ & $2(0)$ & $0(0)$ & $2(0)$ \\
\hline N/A & $10(5)$ & $0(0)$ & $0(0)$ & $0(0)$ & $0(0)$ & $0(0)$ & $0(0)$ & $1(0)$ & $8(5)$ & $1(0)$ & $10(5)$ \\
\hline Total & $21(10)$ & $5(5)$ & $2(2)$ & $1(0)$ & $3(2)$ & $2(2)$ & $2(2)$ & $2(1)$ & $29(19)$ & $5(3)$ & $36(23)$ \\
\hline
\end{tabular}

\section{Discussion}

A systematic review is focused on the analysis of the body of empirical research on the relations between digital games and learning styles or multiple intelligences. The query of the repositories identified a large number of papers related to using games in education. Further analysis confirmed the authors' stance that the interest in exploring the effects of digital games on students (and learning in general) has increased in the last decade. However, the papers mainly presented theoretical considerations and discussions on using games that did not concern learning styles or multiple intelligences, nor were supported by the adequate empirical evidence, thus these were excluded from the review. Criteria analysis identified 36 papers, by which the doubt in a small set of empirical evidence was justified. Representative papers varied in research objectives, theoretical framework and methodology, as a consequence of interdisciplinarity and different authors' interest in studying digital games.

As the meta-analysis did not prove to be the adequate method due to a variety of samples, environments, and research methodologies, the review is presented in the narrative form.

Digital games development and the analysis of learning style influence have been presented in seven selected papers. Hwang et al. (2015) developed RPG to assess the achievements and the motivation by quasi-experiment on a sample of 87 Taiwanese elementary school students, aged 12 . They concluded that 48 students in the experimental group achieved significantly better results and were positively motivated due to the contextual GBL approach and the active learning style. The result is in accordance with Lee $\&$ Butler's (2003) attitude that authentic activities are the base of problem-solving context. Erhel \& Jamet (2013) pointed that while playing the contextual educational computer games, students with primary active learning style achieved better performance than those with prominent reflective style. Boctor (2013) 
used the active learning strategy and developed the "Nursopardy" association game for medical high school students with the aim to evaluate its effectiveness in teaching. The learning styles of 39 students were first examined, and the design of the game was then adapted to the results. Students' attitudes were assessed after playing the game. The majority of students considered the game useful in new knowledge acquisition and as a supplement lecture material. Soflano et al. (2015a) developed adaptive RPG for learning SQL based on Felder and Silverman's (1988) learning style model. The research sample consisted of 120 students. Results show that GBL enhanced the students' achievement and motivation, but that there was no influence on efficiency depending on learning styles. Giles (2015) developed the game named "Mystery at the Library" in accordance with the learning styles with the intent to inform engineering students about the potentials of the university library. A sample of 44 students was interviewed, and it was concluded that the students positively reacted to the game and were positively motivated. Leach \& Sugarman (2005) also demonstrated the positive influence of jeopardy-style educational games on the library instruction and motivation. They developed the game at Georgia State University. Hwang et al. (2012) created a personalized RPG based on the results of the Felder-Silverman learning style questionnaire (1988). A group of 46 elementary school students participated in the research within the natural science course. They concluded that the students that played the game adapted to their learning style demonstrated significantly better achievement and positive motivation. Cheng \& Chen (2008) used the online gaming platform as the support for learning the natural sciences elementary school subjects. The research was realized as the quasi-experiment on two fifth grade classes. The results demonstrated no statistically significant advantage of using the online GBL approach, but students and parents presented the positive attitude and confidence in this system of education.

Higher graded representative papers on developing games in relation to the learning styles have been published in the last three years, which can be explicated as a sign of maturity and a clear and accepted theoretical basis, hence the researchers are gradually starting to practically implement previously limited experimental findings.

The research on effects of digital games on learning styles was presented in 19 selected representative papers. Chwif \& Barretto (2003) created the taxonomy for the games in operational management and presented the models of practical implementations in relation to the students' learning styles. They concluded that the created didactical model of simulation is an effective instructional technique. Ahmet et al. (2011) explored the possibility of using Nintendo Wii sensors in combination with video games for the purpose of creating the tools for studying the basic concepts in physics. The learning style of 18 Swedish elementary school students was assessed by the questionnaire based on Dunn and Dunn (1978) model. The creation of digital interactive environment successfully enhanced the cooperation between students and made learning more interesting and fun. Sylvén and Sundqvist (2012) explored 
the relations between playing computer games and learning English on the sample of 86 Swedish elementary school students, aged 11-12. They noticed the direct correlation between the time spent playing and the language test results, and that the boys performed better than the girls. Feldman et al. (2014) used the "Equilibrium" game for assessing the adoption of abstract concepts and creative complex problem solving. They concluded that the perception style was successfully determined by the Equilibrium computer game and the Index of learning styles questionnaire on the sample of 63 computer science students, with the precision of $85.1 \%$. Soflano et al. (2015b) identified the learning style adaptation while playing the created educational computer game on the sample of 60 students. Before the experiment, participants completed the Felder-Silverman learning style questionnaire (1988) with the aim of determining the preferred learning style, and the interaction with the game was analysed while playing to repeat the learning style identification. The research demonstrated that the learning style adapted while the game was being played if it meant that the goal would be reached faster. Snyder et al. (2009) performed the analysis of the virtual reality simulator training on 36 medical students, and concluded that the simulation did not show statistically significant advantages compared to the traditional methods of teaching. Malekian et al. (2012) investigated the effects of educational games on spatial intelligence by quasi-experiments on the sample of 40 high school students. This proved the existence of the correlation between spatial intelligence and the complementary educational images. Lynch et al. (2008) investigated the influence of the web-based game on the learning styles and achievements on the sample of 300 US students. They concluded that the results of the experiment did not present statistically significant correlation between gameplay and learning styles. Bekebrede et al. (2011) explored the effects of playing 23 digital games on a sample of 1,607 Dutch students and confirmed the existence of the relation between learning style and gameplay, primarily through the promotion of active and collaborative learning. Corbeil and Laveault (2008) evaluated the validity of using digital games in history teaching on a sample of 65 students. They stated that the effects of the games were on average as effective as traditional lectures, and that the simulations benefit mostly students that needed help in constructing concrete operational thinking. They concluded that playing positively motivated students who preferred the sensorymotor learning style. Arora and Saxena Arora (2015) presented the interdisciplinary experimental laboratory game "SC-Mark" created for marketing and management training. Total of 161 students participated in the experiment during two semesters. Experimental gameplay and the simulations have proven to make an effective training environment for realistic business situations. Ku et al. (2014) developed the system for learning Chinese language idioms by playing a computer game. On a sample of 56 Taiwanese elementary school students they determined that the students with the identified active and visual learning style performed significantly better. Dempsey et al. (2002) tested the influence of different game genres on a sample of 40 adult 
respondents aged 18 to 52 . They observed that the simulations and arcade games had markedly different effects on the population depending on gender, as the females were less motivated and considered arcade games as aggressive. Based on the Kolb's (2014) questionnaire, a high percentage of female respondents were accommodators and divergers, while the male respondents were mainly convergers and assimilators. Van Deventer and White (2002) examined seven teenage expert video game players, aged 10-11. They concluded that the "advanced" players demonstrated active search for new information, better assessment of the unknown situations, information categorization, and critical thinking skills. Hwang et al. (2013) explored the students' perception in selecting the most valuable education system from the perspective of learning styles based on the Felder-Silverman model. They analysed the performance of 288 students, and determined that there are no differences in selecting educational games based on genre, nor on learning style, but that it is commonly performed by intuition or personal preference. Kellner and Weißenbacher (2012) integrated the learning style test in educational game. On a sample of 28 adolescents aged 12-13, they determined that it is possible to successfully perform this integration using Vester's (1991) test. Hwang et al. (2008) examined the effects of playing Second Life MMO game (Molka-Danielsen \& Deutschmann, 2009) on the students' spatial perception and learning style. The sample consisted of 73 Korean students, aged 20-22. They concluded that this activity was more effective on a group of students with the abstract conceptualization style.

Representative papers that researched the influence of the digital games on learning styles are diverse in terms of methodology, learning styles model or game genre. Most selected papers (87.5\%) proved the existence of the correlation between playing digital games and learning styles.

The implementation of the digital games in relation to the learning style or intelligences was discussed in four selected papers. Iqbal et al. (2010) used the Second Life MMO game as a platform for adult education in the context of language learning. They pointed out that their adaptive learning model was created in line with the theory of multiple intelligences with the aim to bridge the differences between the learning approaches and technology. The learning materials were presented in accordance with the students' multiple intelligences profile, thus providing a wide range of opportunities for participation in informal education and learning experience improvement. Gosalia et al. (2015) applied the "MathMazing" game based on the gesticulation for teaching arithmetic in elementary school. They concluded that the effective and practical teaching was realized, leading to the improvement of the learning retention. Li et al. (2012) analysed the educational games theory and its relation to the multiple intelligences. They elaborated on the effects of educational games on the development of logical/mathematical intelligence and the strategies of intelligences development. In their literature analysis, Bennett et al. (2008) demonstrated the lack 
of empirical evidence that the new student generations and digital game players possess sophisticated technological skills and have specific learning styles, so that the traditional education system cannot adequately meet the needs of these students.

Four papers focused on the theoretical basis of the digital games application in accordance with the learning styles or multiple intelligences. Howard (2005) suggested strategies for the development of communicational skills and the inclusive environment, taking into account the learning styles, interactive games, and collaborative learning. Kapp (2007) discussed the informal methods of transferring knowledge to the players and their application in the organizations. Bellotti et al. (2010) developed the visual toolkit with the aim of presenting quality contextualized information in the virtual world in line with the learning styles, so that the students can benefit most while playing digital games. González et al. (2007) developed the platform in order to increase the interaction and the social communication amongst children in the context of special education. The concept is based on the personally designed pictograms through which the children can associate grammatical structures with their ideas while having fun. They concluded that playing digital games can help achieve better spatial coordination, concentration, and motivation.

Two representative review papers have been identified. A systematic review by Blakely et al. (2009) stands out, as they performed the analysis of the research on using educational games in health sciences in the period 1980-2008. Having identified 1,829 papers, they presented a detailed analysis of the 16 selected papers that met the selection criteria. They concluded that playing games can support certain learning styles, but failed to support the claim by presenting the adequate empirical research. Ypsilanti et al. (2014) explored the factors of using SG as a mean of informal learning. The results presented a very small number of examples of the implementation and research on the effectiveness of using SG as the teaching method.

The overview of the selected representative papers is presented in the Appendix. The results of the analysis show that the researchers often used case studies and experiments. Although the COTS and MMO games are widespread and students usually play only these games, a surprisingly small number of papers have analysed their effects on learning or personality. The general conclusion is that playing digital games usually leads to the improvement of students' cognitive abilities and skills. Students with the active and visual learning style can gain more by playing digital games, as can students with higher logical/mathematical, visual/spatial or bodily/ kinesthetic intelligence. We observe that the research has mostly been geared towards PC games, usually simulations and puzzles, probably because their use in education has been established longer than on other platforms. The relevant weakness of many research papers concerns the design and the applied methods, as the samples are often not sufficiently representative, so the observed effects could be due to the differences between respondents, not the result of intervention. 


\section{Limitations}

A systematic review has been created with certain limitations, such as search terms, available repositories, and the defined time-frame in which the papers were published. Nevertheless, the papers that have met the criteria and qualitative analysis requirements can be considered a valid sample of empirical evidence on the effects of digital games on learning styles and multiple intelligences. The review excluded the papers solely based on theory or speculation.

\section{Conclusions}

The multi-criteria analysis of research on the relations between digital games and learning styles or multiple intelligences provided a framework for the organization of the results and the identification of the positive effects or difficulties. Although the systematic literature review presented some empirical evidence, the need for additional research is evident. Qualitative research would help better understanding and the identification of methods for more efficient implementation of digital games in education, specifically in using the potential of the learning styles and multiple intelligences psychological theories.

In order to implement the digital game-based learning model as a valid addition to the modern education, it is necessary to constantly evaluate its new forms and the influence on the learning process, characteristics and styles. Although the concept of multiple intelligences has barely begun the transformation from a theoretical framework to practical application, many teachers are already unconsciously working in accordance with it. The introduction of appropriate digital games, guiding students and planning the activities adapted to the learning styles or multiple intelligences can present them with the opportunity for a better and more efficient adoption of new knowledge and skills.

Although a systematic review expanded understanding of categorization and identification of digital games effect on learning styles and intelligences, certain questions for future research should be posed:

- Should the implementation of digital games in education influence learning styles, or should the games be created/adapted to the learning styles?

- Should the focus of the application of digital games in line with multiple intelligences be easier knowledge acquisition, perceptual/cognitive skills development, positive affective/motivational outcome or behavioural change?

Traditional instructional framework presents an emotional, social and cognitive experience in which teachers use their knowledge, voice or movement to address students with the information and questions. Giannakos and Vlamos (2013) stated that humour can lead students to get more involved in educational process and makes the atmosphere in the classroom enjoyable.

The authors do not expect (nor predict) that digital games can replace traditional, blended, electronic or distance learning, but emphasize the importance of using 
various tools in teaching and learning practice outside the conventional framework to successfully span the spectrum of learning styles and intelligences.

\section{References}

Ahmet, Z., Jonsson, M., Sumon, S. I., \& Holmquist, L. E. (2011). Supporting embodied exploration of physical concepts in mixed digital and physical interactive settings. In Proceedings of the fifth international conference on Tangible, embedded, and embodied interaction (pp. 109-116). ACM. https://doi.org/10.1145/1935701.1935723

Anderson, C. A., \& Bushman, B. J. (2001). Effects of violent video games on aggressive behavior, aggressive cognition, aggressive affect, physiological arousal, and prosocial behavior: A meta-analytic review of the scientific literature. Psychological science, 12(5), 353-359. https://doi.org/10.1111/1467-9280.00366

Anderson, C. A., \& Dill, K. E. (2000). Video games and aggressive thoughts, feelings, and behavior in the laboratory and in life. Journal of Personality and Social Psychology, 78(4), 772-790. https://doi.org/10.1037/0022-3514.78.4.772

Armstrong, T. (2000). Multiple intelligences in the classroom. 2nd ed. Alexandria, VA: Association for Supervision and Curriculum Development.

Arora, A., \& Saxena Arora, A. (2015). “Supply Chain - Marketing Shark Tank” Experiential Lab Game in Interdisciplinary Business Education: Qualitative and Quantitative Analyses. Decision Sciences Journal of Innovative Education,13(1), 21-43. https://doi.org/10.1111/ dsji. 12053

Bailey, T., \& Forbes, J. (2005). Just-in-time teaching for CS0. In ACM SIGCSE Bulletin (Vol. 37, No. 1,pp. 366-370). New York, NY: ACM Press. https://doi.org/10.1145/1047124.1047469

Bekebrede, G., Warmelink, H. J. G., \& Mayer, I. S. (2011). Reviewing the need for gaming in education to accommodate the net generation. Computers \& Education, 57(2), 1521-1529. https://doi.org/10.1016/j.compedu.2011.02.010

Bellotti, F., Berta, R., De Gloria, A., \& Primavera, L. (2010). Supporting authors in the development of task-based learning in serious virtual worlds. British Journal of Educational Technology, 41(1), 86-107. https://doi.org/10.1111/j.1467-8535.2009.01039.x

Bennett, S., Maton, K., \& Kervin, L. (2008). The 'digital natives' debate: A critical review of the evidence. British Journal of Educational Technology, 39(5), 775-786. https://doi.org/10.1111/ j.1467-8535.2007.00793.x

Blakely, G., Skirton, H., Cooper, S., Allum, P., \& Nelmes, P. (2009). Educational gaming in the health sciences: systematic review. Journal of Advanced Nursing, 65(2), 259-269. https:// doi.org/10.1111/j.1365-2648.2008.04843.x

Boctor, L. (2013). Active-learning strategies: The use of a game to reinforce learning in nursing education. A case study. Nurse education in practice, 13(2), 96-100. https://doi. org/10.1016/j.nepr.2012.07.010

Booth, R., \& O'Brien, P. J. (2008). A holistic approach for counsellors: Embracing multiple intelligences. International Journal for the Advancement of Counselling, 30(2), 79-92. https:// doi.org/10.1007/s10447-008-9046-0 
Bopp, M. (2007). Storytelling as a motivational tool in digital learning games. In T. Hug (Ed.), Didactics of Microlearning. Concepts, Discourses and Examples (pp. 250-266). Münster: Waxmann Verlag GmbH.

Boyle, E., Connolly, T. M., \& Hainey, T. (2011). The role of psychology in understanding the impact of computer games. Entertainment Computing, 2(2), 69-74. https://doi. org/10.1016/j.entcom.2010.12.002

Cheng, Y. M., \& Chen, P. F. (2008). Building an online game-based learning system for elementary school. In Intelligent Information Hiding and Multimedia Signal Processing, 2008. IIHMSP'08 International Conference (pp. 35-38). IEEE. https://doi.org/10.1109/ IIH-MSP.2008.328

Chorianopoulos, K., Giannakos, M. N., \& Chrisochoides, N. (2014). Design Principles for Serious Games in Mathematics. In Proceedings of the 18th Panhellenic Conference on Informatics (pp. 1-5). ACM. https://doi.org/10.1145/2645791.2645843

Chwif, L., \& Barretto, M. R. P. (2003). Perspectives on simulation in education and training: simulation models as an aid for the teaching and learning process in operations management. In Proceedings of the 35th conference on Winter simulation: driving innovation (pp. 1994-2000). Winter Simulation Conference.

Connolly, T. M., Boyle, E. A., MacArthur, E., Hainey, T., \& Boyle, J. M. (2012). A systematic literature review of empirical evidence on computer games and serious games. Computers \& Education, 59(2), 661-686. https://doi.org/10.1016/j.compedu.2012.03.004

Connolly, T. M., Stansfield, M. H., \& Hainey, T. (2008). Development of a general framework for evaluating games-based learning. In Proceedings of the 2nd European conference on games-based learning. (pp. 105-114). Barcelona, Spain: Universitat Oberta de Catalunya.

Corbeil, P., \& Laveault, D. (2008). Validity of a Simulation Game as a Method for History Teaching. Simulation \& Gaming, 42(4), 462-475. https://doi.org/10.1177/1046878108325451

Corti, K. (2006). Games-based Learning; a serious business application. Informe de PixelLearning, 34(6), 1-20.

De Freitas, S. (2006). Learning in immersive worlds. London: Joint Information Systems Committee.

Dempsey, J. V., Haynes, L. L., Lucassen, B. A., \& Casey, M. S. (2002). Forty simple computer games and what they could mean to educators. Simulation \& Gaming, 33(2), 157-168. https://doi.org/10.1177/1046878102332003

Dempsey, J., Lucassen, B., Gilley, W., \& Rasmussen, K. (1993). Since Malone's theory of intrinsically motivating instruction: what's the score in the gaming literature? Journal of Educational Technology Systems, 22(2), 173-183. https://doi.org/10.2190/2TH7-5TXGTAR7-T4V2

Dempsey, J. V., Lucassen, B., \& Rasmussen, K. (1996). The instructional gaming literature: Implications and 99 sources. Columbia, SC: University of South Carolina, College of Education.

Dorman, S. M. (1997). Video and computer games: Effect on children and implications for health education. Journal of School Health, 67(4), 133-138. https://doi. org/10.1111/j.1746-1561.1997.tb03432.x

Dunn, R. S., \& Dunn, K. J. (1978). Teaching students through their individual learning styles: A practical approach. Reston, VA: Prentice Hall. 
Aleksić and Ivanović: A Literature Review of Empirical Research on the Effects of Digital Games on Learning ...

El-Nasr, M. S., \& Smith, B. K. (2006). Learning through game modding. Computers in Entertainment (CIE), 4(1), 45-64. https://doi.org/10.1145/1111293.1111301

Erhel, S., \&Jamet, E. (2013). Digital game-based learning: Impact of instructions and feedback on motivation and learning effectiveness. Computers \& Education, 67, 156-167. https://doi.org/10.1016/j.compedu.2013.02.019

Felder, R. M. (1993). Reaching the second tier - Learning and Teaching Styles in College Science Education. Journal of College Science Teaching, 23(5), 286-290.

Felder, R. M. (1996). Matters of Styles. ASEE Prism, 6(4), 18-23.

Felder, R. M., \& Silverman, L. K. (1988). Learning and teaching styles in engineering education. Engineering Education, 78(7), 674-681.

Feldman, J., Monteserin, A., \& Amandi, A. (2014). Detecting students' perception style by using games. Computers \& Education, 71, 14-22. https://doi.org/10.1016/j.compedu.2013.09.007

Ferguson, C. J. (2007). The good, the bad and the ugly: A meta-analytic review of positive and negative effects of violent video games. Psychiatric Quarterly, 78(4), 309-316. https:// doi.org/10.1007/s11126-007-9056-9

Ferguson, C. J., Rueda, S. M., Cruz, A. M., Ferguson, D. E., Fritz, S., \& Smith, S. M. (2008). Violent video games and aggression: causal relationship or byproduct of family violence and intrinsic violence motivation? Criminal Justice and Behavior, 35(3), 311-332. https:// doi.org/10.1177/0093854807311719

Fleming, N. D. (2006). Teaching and learning styles: VARK strategies. Christchurch, New Zealand: N.D. Fleming.

Foss, B. A., \& Eikaas, T. (2006). Game Play in Engineering Education - Concept and Experimental Results. International Journal of Engineering Education, 22(5), 1043-1052.

Gardner, H. E. (1985). Frames of mind: The theory of multiple intelligences. New York: Basic Books.

Gardner, H. E. (1993). Multiple Intelligences: The Theory in Practice. New York: Basic Books.

Garris, R., Ahlers, R., \& Driskell, J. E. (2002). Games, motivation, and learning: A research and practice model. Simulation \& Gaming, 33(4), 441-467. https://doi. org/10.1177/1046878102238607

Giannakos, M. N., \& Vlamos, P. (2013). Using webcasts in education: Evaluation of its effectiveness. British Journal of Educational Technology, 44(3), 432-441. https://doi. org/10.1111/j.1467-8535.2012.01309.x

Giles, K. (2015). No Budget, No Experience, No Problem: Creating a Library Orientation Game for Freshman Engineering Majors. The Journal of Academic Librarianship, 41(2), 170-177. https://doi.org/10.1016/j.acalib.2014.12.005

González, J., Cabrera, M., \& Gutiérrez, F. (2007). Using videogames in special education. Computer Aided Systems Theory-EUROCAST 2007, 360-367. https://doi.org/10.1007/978$\underline{3-540-75867-9 \quad 46}$

Gosalia, N., Jain, P., Shah, I., Joshi, A. R., Katre, N., \& Sahasrabudhe, S. (2015). 3D Gesturerecognition Based Animation Game. Procedia Computer Science, 45, 712-717. https://doi. org/10.1016/j.procs.2015.03.138

Griffiths, M. D., \& Davies, M. N. O. (2002). Excessive online computer gaming: implications for education. Journal of Computer Assisted Learning, 18, 379-380. https://doi.org/10.1046/ j.0266-4909.2002.00248.x 
Griffiths, M. D., \& Hunt, N. (1995). Computer game playing in adolescence: Prevalence and demographic indicators. Journal of Community \& Applied Social Psychology, 5(3), 189-193. https://doi.org/10.1002/casp.2450050307

Grissom, S., McNally, M. F., \& Naps, T. (2003). Algorithm visualization in CS education: comparing levels of student engagement. In Proceedings of the 2003 ACM symposium on Software visualization (pp. 87-94). ACM. https://doi.org/10.1145/774833.774846

Hays, R. T. (2005). The effectiveness of instructional games: A literature review and discussion. Tech. Rep. 2005-004, Naval Air Warfare Center. Orlando, FL: Training Systems Division.

Heidegger, M., \& Lovitt, W. (1977). The question concerning technology, and other essays. London: Harper and Row.

Herz, J. C. (1997). Joystick nation: How videogames ate our quarters, won our hearts, and rewired our minds. Boston, MA: Little, Brown and Company.

Higgins, J. P., \& Green, S. (2008). Front Matter. New York, NY: John Wiley \& Sons. https:// doi.org/10.1002/9780470712184.fmatter

Hoffman, E. (2002). Psychological testing at work. New York: McGraw-Hill.

Honey, P., \& Mumford, A. (2000). The learning styles helper's guide. Maidenhead, Berkshire: Peter Honey.

Howard, E. V. (2005). Promoting communication and inclusiveness in the IT classroom. In Proceedings of the 6th conference on Information technology education (pp.311-317). ACM. https://doi.org/10.1145/1095714.1095786

Hwang, G. J., Chiu, L. Y., \& Chen, C. H. (2015). A contextual game-based learning approach to improving students' inquiry-based learning performance in social studies courses. Computers \& Education, 81, 13-25. https://doi.org/10.1016/j.compedu.2014.09.006

Hwang, J., Park, H., Cha, J., \& Shin, B. (2008). Effects of object building activities in Second Life on players' spatial reasoning. In Digital Games and Intelligent Toys Based Education, 2008 Second IEEE International Conference on (pp. 62-69). IEEE. https://doi.org/10.1109/ digitel.2008.14

Hwang, G. J., Sung, H. Y., Hung, C. M., Huang, I., \& Tsai, C. C. (2012). Development of a personalized educational computer game based on students' learning styles. Educational Technology Research and Development, 60(4), 623-638. https://doi.org/10.1007/s11423012-9241-X

Hwang, G. J., Sung, H. Y., Hung, C. M., \& Huang, I. (2013). A learning style perspective to investigate the necessity of developing adaptive learning systems. Journal of Educational Technology \& Society, 16(2), 188-197.

Iqbal, T., Hammermüller, K., \& Tjoa, A. M. (2010). Second life for illiterates: a 3D virtual world platform for adult basic education. In Proceedings of the 12th International Conference on Information Integration and Web-based Applications \& Services (pp. 373-380). ACM. https://doi.org/10.1145/1967486.1967545

Jung, C. G. (2014). The development of personality. New York, NY: Routledge.

Juul, J. (2011). Half-real: Video games between real rules and fictional worlds. Cambridge, MA: MIT Press.

Kagan, S., \& Kagan, M. (1998). Multiple intelligences: the complete MI book. San Clemente, CA: Kagan Cooperative Learning. 
Aleksić and Ivanović: A Literature Review of Empirical Research on the Effects of Digital Games on Learning ...

Kapp, K. M. (2007). Tools and techniques for transferring know-how from boomers to gamers. Global Business and Organizational Excellence, 26(5), 22-37. https://doi. org/10.1002/joe.20162

Ke, F. (2009). A qualitative meta-analysis of computer games as learning tools. In R. Ferdig (Ed.), Handbook of research on effective electronic gaming in education (pp. 1-32). Hershey, PA: IGI Global. https://doi.org/10.4018/978-1-59904-808-6.ch001

Kelleher, C., Pausch, R., \& Kiesler, S. (2007). Storytelling Alice motivates middle school girls to learn computer programming. In Proceedings of the SIGCHI conference on Human factors in computing systems (pp. 1455-1464). ACM. https://doi.org/10.1145/1240624.1240844

Kellner, G., \& Weißenbacher, A. (2012). GETOLS: Game Embedded Testing of Learning Strategies. In Digital Game and Intelligent Toy Enhanced Learning (DIGITEL), 2012 IEEE Fourth International Conference on (pp. 9-16). IEEE. https://doi.org/10.1109/ DIGITEL.2012.10

Khan, K. S., Ter Riet, G., Glanville, J., Sowden, A. J., \& Kleijnen, J. (2001). Undertaking systematic reviews of research on effectiveness: CRD's guidance for carrying out or commissioning reviews (No. 4 (2nd Edition)). York, United Kingdom: NHS Centre for Reviews and Dissemination.

Kirriemuir, J., \& McFarlane, A. (2004). Literature review in games and learning. A Graduate School of Education, University of Bristol: Futurelab.

Kolb, D. A. (2014). Experiential learning: Experience as the source of learning and development. Upper Saddle River, NJ: Pearson Education.

$\mathrm{Ku}, \mathrm{D}$. T., Huang, Y.-H., \& Hus, S.-C. (2014). The effects of GBL and learning styles on Chinese idiom by using TUI device. Journal of Computer Assisted Learning, 31(6), 505515. https://doi.org/10.1111/jcal.12085

Leach, G. J., \& Sugarman, T. S. (2005). Play to win! Using games in library instruction to enhance student learning. Research Strategies, 20(3), 191-203. https://doi.org/10.1016/j. resstr.2006.05.002

Lee, H. S., \& Butler, N. (2003). Making authentic science accessible to students. International Journal of Science Education, 25(8), 923-948. https://doi.org/10.1080/09500690305023

Li, J., Ma, S., \& Ma, L. (2012). The Study on the Effect of Educational Games for the Development of Students' Logic-Mathematics of Multiple Intelligence. Physics Procedia, 33, 1749-1752. https://doi.org/10.1016/j.phpro.2012.05.280

Lynch, R. A., Dale Steen, M., Pritchard, T. J., Buzzell, P. R., \& Pintauro, S. J. (2008). Delivering Food Safety Education to Middle School Students Using a Web-Based, Interactive, Multimedia, Computer Program. Journal of Food Science Education, 7(2), 35-42. https:// doi.org/10.1111/j.1541-4329.2007.00046.x

Malekian, F., Pour, A. R. F., \& Pour, B. S. (2012). Study the Effect of Supplemental Instructional Images on Students' Spatial Intelligence Degree. Procedia-Social and Behavioral Sciences, 46, 3301-3305. https://doi.org/10.1016/j.sbspro.2012.06.055

Malone, T. W. (1981). Toward a theory of intrinsically motivating instruction. Cognitive Science, 5(4), 333-369. https://doi.org/10.1207/s15516709cog0504 2

Molka-Danielsen, J., \& Deutschmann, M. (2009). Learning and teaching in the virtual world of Second Life. Trondheim, Norway: Tapir Academic Press.

Moran, S., Kornhaber, M., \& Gardner, H. (2006). Orchestrating multiple intelligences. Educational Leadership, 64(1), 22-27. 
Murphy, J. (1992). Effective schools: Legacy and future directions. In D. Reynolds \& P. Cuttance (Eds.), School effectiveness: Research, policy and practice (pp. 164-170). New York, NY: Cassell.

Myers, I., \& Myers, P. (2010). Gifts differing: Understanding personality type. Mountain View, CA: Davies-Black Publishing.

O’Neil, H. F., Wainess, R., \& Baker, E. L. (2005). Classification of learning outcomes: Evidence from the computer games literature. The Curriculum Journal, 16(4), 455-474. https://doi. org/10.1080/09585170500384529

Ogletree, S. M., \& Drake, R. (2007). College students' video game participation and perceptions: Gender differences and implications. Sex Roles, 56(7-8), 537-542. https:// doi.org/10.1007/s11199-007-9193-5

Park, J. H., Abirached, B., \& Zhang, Y. (2012). A framework for designing assistive technologies for teaching children with ASDs emotions. In CHI'12 Extended Abstracts on Human Factors in Computing Systems (pp. 2423-2428). ACM. https://doi.org/10.1145/2212776.2223813

Pasin, F., \& Giroux, H. (2011). The impact of a simulation game on operations management education. Computers \& Education, 57(1), 1240-1254. https://doi.org/10.1016/j. compedu.2010.12.006

Petersen, K., Feldt, R., Mujtaba, S., \& Mattsson, M. (2008). Systematic mapping studies in software engineering. In G. Visaggio, M. Baldassarre, S. Linkman \& M. Turner (Eds.), 12th international conference on Evaluation and Assessment in Software Engineering (pp. 68-77). Bari, Italy: University of Bari.

Petticrew, M., \& Roberts, H. (2008). Systematic Reviews in the Social Sciences: A Practical Guide. Oxford, United Kingdom: Blackwell Publishing.

Piaget, J. (1976). Piaget's theory. Berlin, Heidelberg: Springer. https://doi.org/10.1007/9783-642-46323-5 2

Prensky, M. (2003). Digital game-based learning. Computers in Entertainment (CIE), 1(1), 21-24. https://doi.org/10.1145/950566.950596

Proserpio, L., \& Gioia, D. A. (2007). Teaching the Virtual Generation. Academy of Management Learning \& Education, 6(1), 69-80. https://doi.org/10.5465/AMLE.2007.24401703

Qiu, L., \& Riesbeck, C. K. (2004). An incremental model for developing computer-based learning environments for problem-based learning. In Advanced Learning Technologies, 2004. Proceedings. IEEE International Conference on (pp. 171-175). Washington, DC: IEEE Computer Society.

Rasmussen, K. L., \& Davidson-Shivers, G. V. (1998). Hypermedia and learning styles: Can performance be influenced? Journal of Educational Multimedia and Hypermedia, 7(4), 291-308.

Reigeluth, C. M. (1996). A new paradigm of ISD? Educational Technology \& Society, 36(3), 13-20.

Robinson, K. (2009). The element: How finding your passion changes everything. London, United Kingdom: Penguin Books Ltd.

Rodrigues, M., \& Carvalho, P. S. (2013). Teaching physics with Angry Birds: exploring the kinematics and dynamics of the game. Physics Education, 48(4), 431-437. https://doi. org/10.1088/0031-9120/48/4/431 
Aleksić and Ivanović: A Literature Review of Empirical Research on the Effects of Digital Games on Learning ...

Roschelle, J., Tatar, D., Chaudhury, S. R., Dimitriadis, Y., Patton, C., \& DiGiano, C. (2007). Ink, improvisation, and interactive engagement: Learning with tablets. Computer, 40(9), 42-48. https://doi.org/10.1109/MC.2007.321

Sawyer, B., \& Smith, P. (2008). Keynote address. In The second European conference on gamesbased learning (pp. 16-17). Barcelona, Spain: Universitat Oberta de Catalunya.

Seery, M. D., Blascovich, J., Weisbuch, M., \& Vick, S. B. (2004). The relationship between selfesteem level, self-esteem stability, and cardiovascular reactions to performance feedback. Journal of pPersonality and Social Psychology 87(1), 133-145. https://doi.org/10.1037/00223514.87.1.133

Sharda, N. K. (2007). Creating innovative new media programs: Need, challenges, and development framework. In Proceedings of the international workshop on Educational multimedia and multimedia education (pp. 77-86). ACM. https://doi. org/10.1145/1290144.1290157

Shearer, B. (2004). Using a multiple intelligences assessment to promote teacher development and student achievement. The Teachers College Record, 106(1), 147-162. https://doi. org/10.1111/j.1467-9620.2004.00325.x

Sindre, G., Natvig, L., \& Jahre, M. (2009). Experimental validation of the learning effect for a pedagogical game on computer fundamentals. IEEE Transactions on Education, 52(1), 10-18. https://doi.org/10.1109/TE.2007.914944

Silver, H. F., Strong, R. W., \& Perini, M. J. (2000). So each may learn. Integrating learning styles and multiple intelligences. Alexandria, VA: Association for Supervision and Curriculum Development.

Snyder, C. W., Vandromme, M. J., Tyra, S. L., \& Hawn, M. T. (2009). Proficiency-based laparoscopic and endoscopic training with virtual reality simulators: a comparison of proctored and independent approaches. Journal of Surgical Education , 66(4), 201-207. https://doi.org/10.1016/j.jsurg.2009.07.007

Soflano, M., Connolly, T. M., \& Hainey, T. (2015a). An application of adaptive games-based learning based on learning style to teach SQL. Computers \& Education, 86, 192-211. https:// doi.org/10.1016/j.compedu.2015.03.015

Soflano, M., Connolly, T. M., \& Hainey, T. (2015b). Learning style analysis in adaptive GBL application to teach SQL. Computers \& Education, 86, 105-119. https://doi.org/10.1016/j. compedu.2015.02.009

Spalter, A. M., Simpson, R. M., Legrand, M., \& Taichi, S. (2000). Considering a full range of teaching techniques for use in interactive educational software: a practical guide and brainstorming session. In Frontiers in Education Conference, 2000. FIE 2000. 30th Annual (Vol. 2, pp. S1D-19). IEEE. https://doi.org/10.1109/fie.2000.896622

Sung, K., Hillyard, C., Angotti, R. L., Panitz, M. W., Goldstein, D. S., \& Nordlinger, J. (2011). Game-themed programming assignment modules: a pathway for gradual integration of gaming context into existing introductory programming courses. IEEE Transactions on Education, 54(3), 416-427. https://doi.org/10.1109/te.2010.2064315

Sylvén, L. K., \& Sundqvist, P. (2012). Gaming as extramural English L2 learning and L2 proficiency among young learners. ReCALL, 24(03), 302-321. https://doi.org/10.1017/ $\underline{\text { S095834401200016X }}$

VanDeventer, S. S., \& White, J. A. (2002). Expert behavior in children's video game play. Simulation \& Gaming, 33(1), 28-48. https://doi.org/10.1177/1046878102033001002 
Vester, F. (1991). Denken, Lernen, Vergessen. Was geht in unserem Kopf vor, wie lernt das Gehirn, und wann lässt es uns im Stich? München, Deutschland: dtv Verlagsgesellschaft.

Wang, A. I., Øfsdahl, T., \& Mørch-Storstein, O. K. (2008). An evaluation of a mobile game concept for lectures. In Proceedings of the IEEE 21st Conference on Software Engineering Education and Training CSEET'08 (pp. 197-204). https://doi.org/10.1109/cseet.2008.15

Wang, A. I., Øfsdahl, T., \& Mørch-Storstein, O. K. (2007). Lecture quiz-a mobile game concept for lectures. In Proceedings of the 11th IASTED International Conference on Software Engineering and Application (SEA'07)(pp.305-310).

Wang, A. I., \& Wu, B. (2009). An application of a game development framework in higher education. International Journal of Computer Games Technology, 2009, 1-12. https://doi. org/10.1155/2009/693267

Weaver, K., Komlodi, A., \& Duffy, B. (2013). Using an intelligent interviewer to perform cognitive assessments. In CHI'13 Extended Abstracts on Human Factors in Computing Systems (pp. 259-264). ACM. https://doi.org/10.1145/2468356.2468403

Wouters, P., van der Spek, E., \& van Oostendorp, H. (2009). Current practices in serious game research: A review from a learning outcomes perspective. In T. Connolly, M. Stansfield, \& E. Boyle (Eds.), Games-based learning advancements for multi-sensory human computer interfaces: techniques and effective practices (pp. 232-250). Hershey, PA: IGI Global. https:// doi.org/10.4018/978-1-60566-360-9.ch014

Wu, B., \& Wang, A. I. (2012). A guideline for game development-based learning: a literature review. International Journal of Computer Games Technology, 2012, 1-20. https://doi. org/10.1155/2012/103710

Ypsilanti, A., Vivas, A. B., Räisänen, T., Viitala, M., Ijäs, T., \& Ropes, D. (2014). Are serious video games something more than a game? A review on the effectiveness of serious games to facilitate intergenerational learning. Education and Information Technologies, 19(3), 515529. https://doi.org/10.1007/s10639-014-9325-9

\section{Veljko Aleksić}

Faculty of Technical Sciences in Čačak, University of Kragujevac Svetog Save 65, 32000 Čačak, Serbia

veljko.aleksic@ftn.kg.ac.rs

\section{Mirjana Ivanović}

Faculty of Sciences, University of Novi Sad

Trg Dositeja Obradovića, 21000 Novi Sad, Serbia

mira@dmi.uns.ac.rs 


\section{Appendix}

\begin{tabular}{|c|c|c|c|c|c|c|c|c|c|c|c|}
\hline Type & Title & Year & Authors & 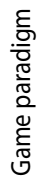 & 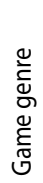 & $\frac{.}{\stackrel{\circ}{\frac{0}{0}}}$ & 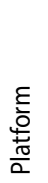 & $\begin{array}{l}\bar{d} \\
\frac{0}{2}\end{array}$ & 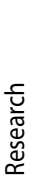 & $\frac{\frac{1}{0}}{\frac{\pi}{0}}$ & 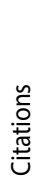 \\
\hline \multirow[t]{7}{*}{ Research } & $\begin{array}{l}\text { Simulation models as } \\
\text { an aid for the teaching } \\
\text { and learning process for } \\
\text { operations management }\end{array}$ & 2003 & $\begin{array}{c}\text { L. Chwif } \\
\text { M. Barretto }\end{array}$ & $\frac{n}{\frac{n}{2}}$ & 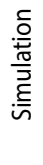 & 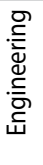 & $\cup$ & 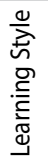 & 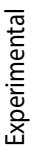 & in & $\Lambda$ \\
\hline & $\begin{array}{l}\text { Supporting Embodied } \\
\text { Exploration of Physical } \\
\text { Concepts in Mixed } \\
\text { Digital and Physical } \\
\text { Interactive Settings }\end{array}$ & 2011 & $\begin{array}{l}\text { Z. Ahmet } \\
\text { M. Jonsson } \\
\text { S. Sumon } \\
\text { L. Holmquist }\end{array}$ & 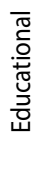 & $\frac{\Sigma}{z}$ & 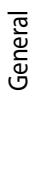 & $\cup$ & 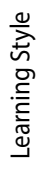 & 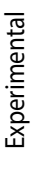 & $\checkmark$ & \\
\hline & $\begin{array}{l}\text { Gaming as extramural } \\
\text { English L2 learning and } \\
\text { L2 proficiency among } \\
\text { young learners }\end{array}$ & 2012 & $\begin{array}{l}\text { L. Sylvén } \\
\text { P. Sundqvist }\end{array}$ & $\stackrel{n}{\frac{0}{2}}$ & $\frac{0}{N}$ & 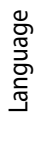 & $\cup$ & 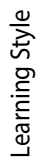 & 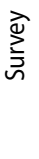 & $m$ & $\cdot$ \\
\hline & $\begin{array}{l}\text { Detecting students' } \\
\text { perception style by using } \\
\text { games }\end{array}$ & 2013 & $\begin{array}{l}\text { J. Feldman } \\
\text { A. Monteserin } \\
\text { A. Amandi }\end{array}$ & 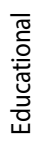 & $\frac{0}{N}$ & 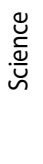 & $\breve{\swarrow ~}$ & 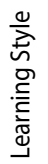 & 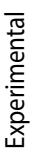 & $\infty$ & $a$ \\
\hline & $\begin{array}{l}\text { Learning Style Analysis } \\
\text { in Adaptive GBL } \\
\text { Application to Teach SQL }\end{array}$ & 2015 & $\begin{array}{l}\text { M. Soflano } \\
\text { T. Connolly } \\
\text { T. Hainey }\end{array}$ & 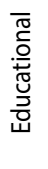 & য় & 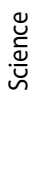 & บ & 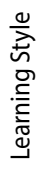 & 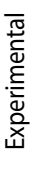 & a & ' \\
\hline & $\begin{array}{l}\text { Proficiency-Based } \\
\text { Laparoscopic and } \\
\text { Endoscopic Training } \\
\text { With Virtual Reality } \\
\text { Simulators: A } \\
\text { Comparison of Proctored } \\
\text { and Independent } \\
\text { Approaches }\end{array}$ & 2009 & $\begin{array}{c}\text { C. Snyder } \\
\text { M. Vandromme } \\
\text { S. Tyra } \\
\text { M. Hawn }\end{array}$ & 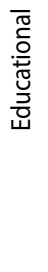 & 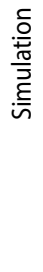 & 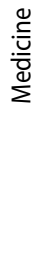 & 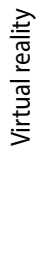 & 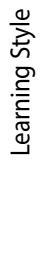 & 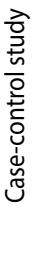 & $\Lambda$ & m \\
\hline & $\begin{array}{l}\text { Study the Effect } \\
\text { of supplemental } \\
\text { instructional images } \\
\text { on students' spatial } \\
\text { intelligence degree }\end{array}$ & 2012 & $\begin{array}{l}\text { F. Malekian } \\
\text { A. Pour } \\
\text { B. Pour }\end{array}$ & 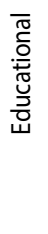 & $\frac{\frac{d}{N}}{2}$ & 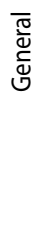 & 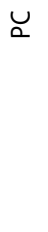 & 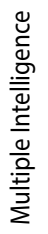 & 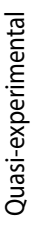 & in & ' \\
\hline
\end{tabular}


Delivering Food Safety

Education to Middle

School Students Using a

Web-Based, Interactive,

Multimedia, Computer

Program

Reviewing the need for gaming in education to accommodate the net generation

Validity of a Simulation Game as a Method for History Teaching

"Supply ChainMarketing Shark Tank" Experiential Lab Game in Interdisciplinary Business Education: Qualitative and Quantitative Analyses

The effects of GBL and learning styles on Chinese idiom by using TUI device

Forty simple computer games and what they could mean to educators

Expert behavior in children's video game play

A Learning Style

Perspective to

Investigate the Necessity of Developing Adaptive Learning Systems

Effects of Object Building 2008 Activities in Second Life on Players' Spatial

Reasoning

2007

2011

2011

2015

2014

2002

2013
R. Lynch
M. Steen
T. Pritchard
P. Buzzell
S. Pintauro

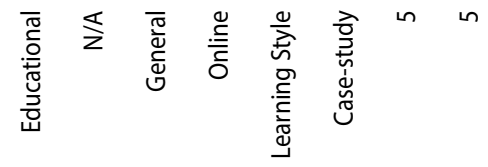

\section{G. Bekebrede \\ H. Warmelink I. Mayer}

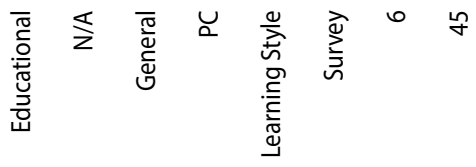

P. Corbeil

D. Laveault

范

彥

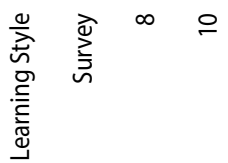

A. Arora

A. Arora

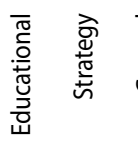

অ্ত

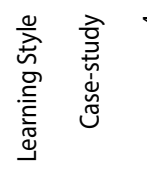

D. Ku

Y. Huang

S. Hust

2002
J. Dempsey
L. Haynes
B. Lucassen
M. Casey

은 $\frac{0}{N}$

峁

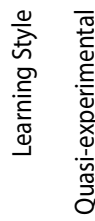

S. VanDeventer J. White
G. Hwang
H. Sung
C. Hung
I. Huang

J. Hwang

H. Park

J. Cha

B. Shin

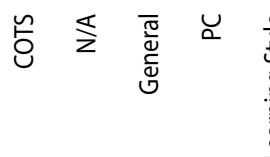

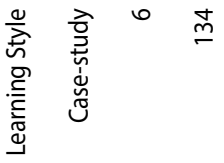

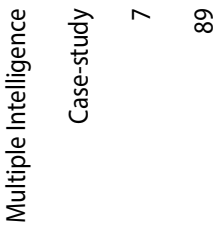

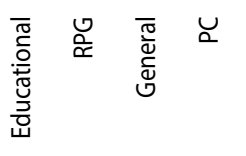

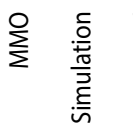

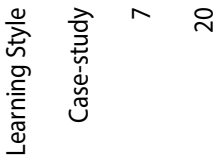

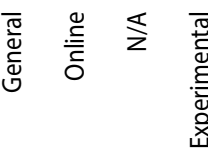


GETOLS: Game

Embedded Testing Of

Learning Strategies

Theory

Promoting

Communication and Inclusiveness in the IT Classroom

Tools and Techniques for Transferring Know-How from Boomers to Gamers

Supporting authors in the development of taskbased learning in serious virtual worlds

Using Videogames in Special Education
2012

G. Kellner
A. Weißenbacher

营

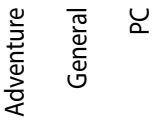

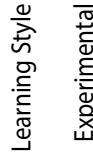

2005

E. Howard

产

$\$$

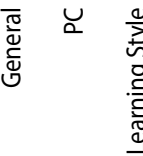

K. Kapp

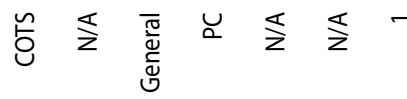

2009

F. Bellotti

R. Berta

A. De Gloria

L. Primavera

2007

J. Gonzalez

M. Cabrera

F. Gutierrez

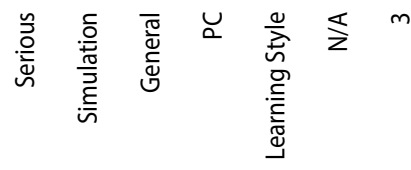

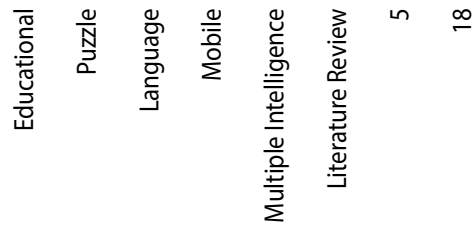

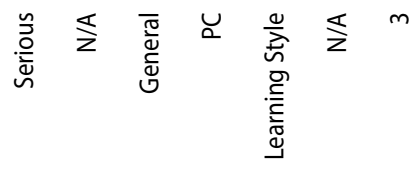

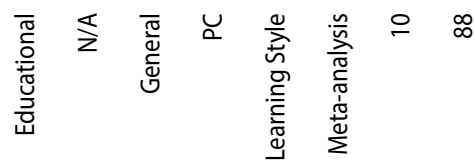

Discussion Second Life for Illiterates:

A 3D Virtual World

Platform for Adult Basic

Education

3D Gesture-Recognition Based Animation Game
T. ljäs

G. Blakely
H. Skirton
S. Cooper
P. Allum
P. Nelmes

2014

2008

2010

T. lqbal

A. Tjoa

$$
\sum_{\sum}^{\circ}
$$

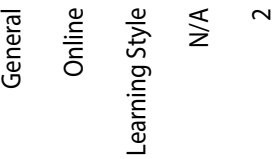

2015
N. Gosalia
P. Jain
I. Shah
A. Joshi
N. Katre

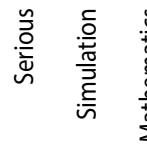
K. Hammermüller

$\stackrel{\frac{0}{0}}{\frac{0}{5}}$ 
The Study on the Effect

2012

of Educational Games

for the Development

of Students' Logic-

mathematics of Multiple

Intelligence

The 'digital natives'

debate: A critical review

of the evidence

Development A contextual gamebased learning approach to improving students' inquiry-based learning performance in social studies courses

Active-learning strategies: The use of a game to reinforce learning in nursing education. A case study

An application of adaptive games-based learning based on learning style to teach SQL

No Budget, No 2014

Experience, No Problem:

Creating a Library

Orientation Game for

Freshman Engineering Majors

Play to win! Using games in library instruction to enhance student learning

Development of a 2012 personalized educational computer game based on students' learning styles

2015

2012

2015

M. Soflano

T. Connolly

2006

T. Sugarman

Building an online game- 2008 based learning system for elementary school
G. Hwang
L. Chiu
C. Chen

L. Boctor

S. Bennett

K. Maton

L. Kervin

T. Hainey

K. Giles
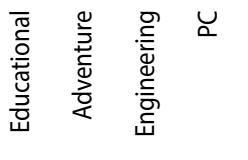

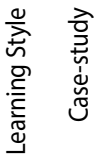

G. Leach

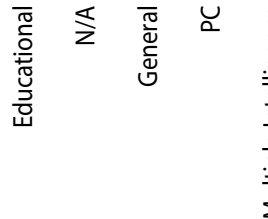

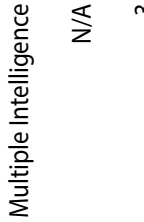

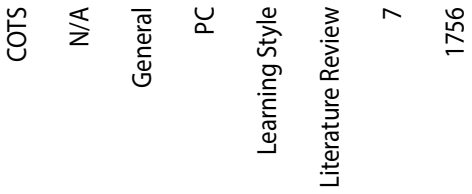

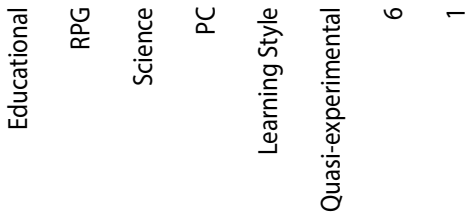

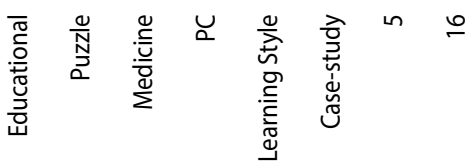

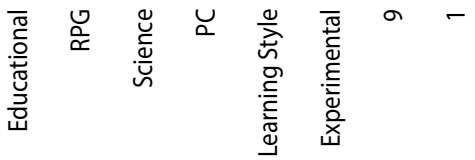

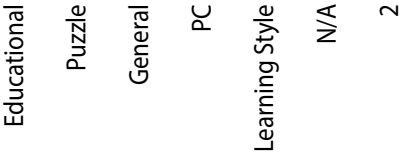

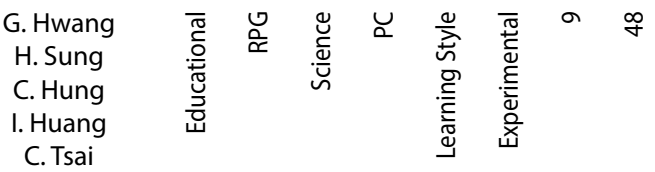

Y. Cheng

P. Chen

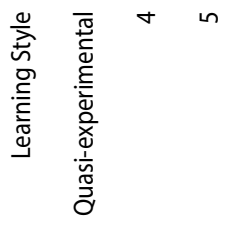




\section{Pregled literature o empirijskim istraživanjima o utjecaju digitalnih igara na stilove učenja i višestruke inteligencije}

\section{Sažetak}

U radu se daje pregled literature koja prikazuje rezultate istraživanja o utjecaju digitalnih igara na učenje i inteligencije učenika. Istraživanje je obuhvatilo 5740 znanstvenih radova iz 11 elektroničkih repozitorija, a koji su pružili raznolike dokaze o višedimenzionalnom utjecaju digitalnih igara na učenike. Kategorizacijom i primjenom višestrukih kvalitativnih kriterija pronađeno je 36 odgovarajućih radova koji su sadržavali empirijske dokaze. U radovima su analizirani raznovrsni indikatori i referentne točke, uzimajući u obzir metodološka ograničenja. Rezultati potvrduju kompleksne veze između digitalnih igara i stilova učenja, kao i višestrukih inteligencija, na temelju kojih se stvaraju preporuke i pitanja za buduća istraživanja.

Ključne riječi: digitalne igre; pregled literature; stil učenja; višestruke inteligencije.

\section{Uvod}

Digitalne igre počele su zauzimati vodeće mjesto u zabavnoj industriji u sedamdesetim godinama prošlog stoljeća i tako promijenile tradicionalne oblike igranja, kao i slobodno vrijeme. Tehnološki napredak, nova hardverska rješenja i brža komunikacija omogućili su razradu i poboljšanje računalnih igara koje sada prožimaju živote mnogih generacija. Računalne i videoigre postale su nezaobilazne u životu djece i adolescenata i imaju važnu ulogu u kulturi mladih (Dorman, 1997). Igre se sada mogu igrati bilo gdje i bilo kada, jer je tehnološki bogato okruženje prepuno prijenosnih računala, pametnih telefona, mobilnih i kućnih igraćih konzola, stolnih računala, kao i drugih digitalnih naprava. Unutarnja motivacija koju mladi imaju za igranje digitalnih igara može se kombinirati s edukativnim sadržajima i ciljevima koje je Prensky (2003) nazvao učenjem utemeljenim na didaktičkim digitalnim igrama.

Stav je autora da se utjecaj digitalnih igara na živote generacija učenika koji već jesu (ili će biti) u školskom sustavu ne smije marginalizirati. Čak naprotiv, igranje modernih digitalnih igara s vizualnim/auditivnim/kinestetičkim sadržajima zasigurno 
utječe na perceptivne, kognitivne, afektivne i psihomotoričke karakteristike igrača i tako izravno vodi prilagodbi stilovima učenja i tipu inteligencije učenika.

Cilj je istraživanja usustavljen pregled literature koja sadrži empirijske dokaze o utjecaju digitalnih igara na stilove učenja i višestruke inteligencije. Analiza može dati korisne informacije nastavnicima iz različitih područja i razina obrazovanja, kao i stručnjacima koji se bave istraživačkim radom u području psihologije, pedagogije, učenja utemeljenog na tehnologiji i učenja utemeljenog na igranju digitalnih igara. U istraživanju su se koristili elementi metode sustavnog mapiranja koja obuhvaća pretraživanje izvora literature kako bi se procijenio opseg i kvaliteta objavljenih radova (npr. empirijskih istraživanja) u određenom interesnom području (Petersen i sur., 2008). Korištenje spomenutom metodom omogućilo je prikupljanje i kategorizaciju radova i pregled literature u interesnom području. Kako bismo uspješno primijenili metodu, najprije smo definirali pitanja istraživanja. Nakon pretraživanja relevantnih repozitorija, odabrani su radovi analizirani i, ako odgovaraju definiranim kriterijima, informacije se prikupljaju, a zatim se rezultati usustavljuju.

Ostatak rada organiziran je na sljedeći način. Sljedeće poglavlje prikazuje prijašnju kategorizaciju istraživačkih radova o digitalnim igrama, stilovima učenja i višestrukim inteligencijama. Dalje opisujemo metodologiju istraživanja, razradu kriterija odabira i okvir analize podataka. Zatim su prikazani rezultati, pa slijedi rasprava i zaključak.

\section{Prijašnja kategorizacija istraživačkih radova}

Iako je intuitivno jasno da igranje digitalnih igara može imati brojne pozitivne učinke, analiza literature je pokazala nedostatak koherentnih i sustavnih istraživanja u toj domeni, što predstavlja prepreku razumijevanju utjecaja koji digitalne igre imaju na učenje. Ta činjenica također otežava i stvaranje empirijski dokazanih prijedloga za učinkovito iskorištavanje potencijala digitalnih igara. Stručnjaci u području suvremenog obrazovanja poklanjaju pažnju mogućnostima implementacije psihologijskih teorija o stilovima učenja i višestrukim inteligencijama u nastavi, što je, uz očigledan utjecaj digitalnih igara na živote učenika, naše istraživanje usmjerilo na ispitivanje potencijalne korelacije između digitalnih igara, stilova učenja i višestrukih inteligencija.

Kako bi se mogla provesti kvalitativna analiza, izrađen je i u daljnjem tekstu prikazan pregled ranije postavljenih i općeprihvaćenih kategorizacija digitalnih igara, stilova učenja i višestrukih inteligencija.

\section{Digitalne igre}

Digitalne igre imaju dvije jedinstvene karakteristike: transmedijalnost i enframing (uokvirivanje). Transmedijalnost se odražava u fenomenu da se igre mogu igrati putem različitih medija (Juul, 2011). Tehnološki je razvoj razlog zbog kojeg moderne digitalne igre smanjuju jaz između virtualnog i stvarnog svijeta, pa se tako igrači sve više stavljaju u situacije da mogu doći u fizički dodir s virtualnim likovima i okolinom. 
Termin enframing odnosi se na digitalno obilježje računalnih igara. Prema Heideggeru i Lovittu (1977), utjecaj moderne tehnologije na oblik igara jest uokvirivanje obilježja i karakteristika virtualnog svijeta koji je stvorio dizajner igre.

Prijašnja istraživanja utjecaja digitalnih igara na učenike uglavnom su bila usredotočena na psihološki i emocionalni utjecaj, često analizom negativnog učinka igranja i veze između nasilnih igara i agresivnog ponašanja. Nije teško naći vezu između igranja videoigara i nasilnog ponašanja, ako to želimo. Griffiths i Hunt (1995) su zaključili da $98,7 \%$ adolescenata u određenoj mjeri igra videoigre, s tim da dječaci više i češće odabiru nasilne igre. U svojoj metaanalizi Anderson i Bushman (2001) navode da igranje nasilnih igara pobuđuje agresivne misli, ponašanje i fiziološko uzbuđenje. Usprkos žestokoj debati među stručnjacima, istraživanja provedena o vezi između nasilnih igara i agresivnog ponašanja donijela su raznolike rezultate. $\mathrm{Na}$ primjer, Anderson i Dill (2000) tvrde da su eksperimentalno dokazali vezu između igara i agresivnog ponašanja, no kada su Ferguson i suradnici (2008) pokušali ponoviti takvo istraživanje primjenom standardiziranog postupka, nisu uspjeli dobiti iste rezultate. Štoviše, jedina veza koju su mogli dokazati bila je ona koja povezuje nasilje $\mathrm{u}$ obitelji s nasilnim igrama i agresivnim ponašanjem. Osim agresijom $\mathrm{u}$ istraživanjima se proučavaju i problemi i nemogućnost kontroliranja vremena koje učenici provedu igrajući igrice (Ogletree i Drake, 2007), kao i veza između igranja digitalnih igara i društvene izoliranosti (Griffiths i Davies, 2002).

Usprkos negativnim konotacijama na samom početku, uskoro je pokazan interes za istraživanje pozitivnog utjecaja igranja digitalnih igara. Ferguson (2007) je u svojoj metaanalizi ispitivao pozitivne i negativne utjecaje igranja digitalnih igara i zaključio da se igranje može povezati s poboljšanjem vizualnih/prostornih vještina. Međutim, razlog zbog kojeg digitalne igre do toga dovode bit će ispitan u nekim budućim istraživanjima.

Očigledan motivacijski faktor i pretpostavka da djeca koja igraju videoigrice mogu razviti neke korisne vještine, naveli su De Freitasa (2006) na promatranje računalnih igara kao nove i privlačne metode učenja. Korištenje edukativnih računalnih igara može biti učinkovito samo ako ciljevi, natjecanje, izazovi i mašta pozitivno utječu na motivaciju za učenje. Motivacija je povezana s početkom, intenzitetom i trajanjem određenog ponašanja. Može se promatrati kao spoj intrinzične motivacije (koja se razvija iz interesa učenika za usvajanje znanja ili ovladavanje vještinom) i ekstrinzične motivacije (koja se temelji na cilju, postizanju ocjene ili izbjegavanju kazne). Iako se na prvi pogled čini atraktivnim, korištenje igara u nastavnom procesu ne djeluje uvijek motivirajuće na učenike. Na primjer, ako je stupanj težine igre previsok, kod učenika će porasti frustracija, što će smanjiti razinu njihova samopouzdanja (Seery i sur., 2004). Uspješno igranje igara uključuje prijelaz na više i teže razine, kao i ovladavanje novim kompetencijama, što rezultira većim uspjehom igrača. $\mathrm{K}$ tomu, osjećaj uživanja u učenju putem igre smanjuje razinu anksioznosti.

Digitalne igre mogu se općenito integrirati u obrazovni proces na tri načina (Sung i sur. 2011; Wang i Wu, 2009): 
- Korištenjem igara umjesto tradicionalnih oblika zadataka učenike se motivira na ulaganje dodatnog truda u rješavanje zadataka, što nastavniku daje mogućnost da nadzire rad učenika u stvarnom vremenu (Foss i Eikaas, 2006; Sindre i sur., 2009);

- Učenjem putem igre povećava se motivacija i sudjelovanje učenika u nastavnom procesu (Wang i sur., 2007, 2008);

- Pružanjem mogućnosti učenicima da modificiraju ili izrade digitalne igre kako bi usvojili vještine u području računalne znanosti (El-Nasr i Smith, 2006). Taj proces naziva se učenjem utemeljenim na izradi igara, a koristi se kako bi se postigao učenički entuzijazam za igranje.

Nakon početnog interesa za korištenje gotovih komercijalnih igara u nastavi (engl. COTS), interes se prebacio na učenje utemeljeno na igrama koje su posebno izrađene za obrazovne svrhe. Rodrigues i Carvalho (2013) su naglasili važnost strategija korištenja popularnih komercijalnih igara (npr. Angry Birds u nastavi fizike), no nisu prikazali primjenu analiziranih pojmova. Bopp (2007) smatra da pripovijedanje $u$ igrama može pozitivno utjecati na motivaciju učenika. Ono je korisno u okruženju u kojem se učenje odvija i pruža mogućnosti za refleksiju, evaluaciju, ilustriranje ili davanje primjera (Kelleher i sur., 2007; Malone, 1981). Suvremene teorije obrazovanja podržavaju pojam aktivnog, iskustvenog i problemskog učenja u kombinaciji s istodobnom povratnom informacijom (Boyle i sur., 2011), što se sve može ostvariti primjenom digitalnih igara. Stručnjaci su također zainteresirani za istraživanja o „ozbiljnim igrama” koje se izrađuju kako bi se utjecalo na ponašanje i stavove, uglavnom u području obrazovanja, zdravstva, marketinga itd.

Istraživanja su uglavnom bila usmjerena na različite načine primjene digitalnih igara u procesu učenja, uglavnom u vezi s kognitivnom domenom. Stav je autora da evaluacija bilo kojeg okruženja u kojemu se odvija učenje (formalno, neformalno i informalno) mora uzeti u obzir kvalitativne aspekte, poput utjecaja na stavove, iskustva, stilove učenja i inteligencije učenika. Osnovni princip smislenog obrazovanja je da svi učenici mogu učiti ako im se pruže odgovarajući individualizirani uvjeti (Robinson, 2009). Ke (2009) smatra da je literatura o računalnim igrama u učenju i poučavanju neusklađena, iako je očigledno da igranje vodi prema mnoštvu pozitivnih ishoda. Nedostatak organiziranosti smatra se preprekom za razumijevanje utjecaja digitalnih igara, za izradu učinkovitijih igara i za kreiranje modela nastave koja se „najbolje” koristi igrama u obrazovnom procesu.

Mnogi stručnjaci predložili su različite kategorizacije digitalnih igara. Kada se izrađuje model kategorizacije, digitalna igra mora se najprije postaviti u odgovarajući okvir, uzimajući u obzir je li izrađena za zabavu, učenje ili kao ozbiljna igra. Gotove komercijalne igre ponajprije su izrađene za zabavu i odmor, a učenje i prilagodba ponašanja glavni su ciljevi igara koje su posebno izrađene za obrazovne svrhe ili ozbiljnih igara, kako se može vidjeti u prikazu 1. Corti (2006) navodi da se igre koje su posebno izrađene za obrazovne svrhe i ozbiljne igre ponekad smatraju istoznačnicama, 
iako su ozbiljne igre izrađene za širu upotrebu u poslovnom području, industriji, marketingu, zdravstvu itd., a ne samo u obrazovanju (Sawyer i Smith, 2008).

\section{Prikaz 1}

Žanr računalne igre određuje se u sklopu utvrđene klasifikacije zabavnih igara, što omogućava koristan način prepoznavanja sličnosti između igara. Iako ne postoji općeprihvaćena taksonomija žanrova digitalnih igara, Herz (1997) je izradio jednu od prvih sistematizacija, sličnu onoj koja se koristi u industriji videoigara:

- akcijske igre (temelje se na reagiranju; to su tipične igre pucanja i platformske igre)

- pustolovne igre (rješavanje logičnih problema kako bi se napredovalo u virtualnom svijetu)

- borbene igre

- slagalice (npr. tetris)

- igranje uloga

- simulacije

- sportske igre

- strategijske igre.

Iako su ti žanrovi relevantni za gotove komercijalne igre, sistematizacija po žanrovima nije potpuno jasna kada se radi o igrama koje su posebno izrađene za obrazovne svrhe ili o ozbiljnim igrama. Moderne tehnologije poput mobilnih igara, online igara, virtualnih svjetova i igara s alternativnom stvarnošću proširile su načine igranja, kao i medije i platforme na kojima se igre igraju. Upravo to zahtijeva adaptaciju Herzove sistematizacije žanrova i njezino proširenje s animiranim tutorijalima, online igrama, mobilnim igrama, virtualnom stvarnošću i kategorijom ostalo.

Uz kategorizaciju bi bilo korisno uzeti u obzir kako se mogu klasificirati dimenzije utjecaja igara na učenike. Vjerojatno je najvažnija klasifikacija ona koja se temelji na vezi između igranja digitalnih igara i ishoda učenja i usvojenog ponašanja. Činjenica da su digitalne igre jako popularne, ide u prilog mišljenju da se mogu primijetiti pozitivna emocionalna iskustva kao poželjan ishod igranja, iako se shvaćanje osjećaja „uživanja” u igranju igara još nije dovoljno ispitalo.

Digitalne se igre sve više proučavaju u kontekstu učenja, pa je do sada izrađeno nekoliko modela za prepoznavanje različitih ishoda učenja koji su rezultat igranja:

- Garris i sur. (2002) su uočili razliku između usvajanja vještina (psihomotoričkih i tehničkih) i kognitivnih (deklarativnih, proceduralnih i strategijskih) i afektivnih (stavovi, uvjerenja i emocionalni utjecaj) postignuća;

- O’Neill i sur. (2005) su prepoznali pet grupa kognitivnih uvjeta koji nisu zadovoljeni tijekom igranja: razumijevanje sadržaja, rješavanje problema, suradnja, komunikacija i samoregulacija;

- Wouters i sur. (2009) su predložili model koji se temelji na četiri vrste postignuća koja se mogu ostvariti igranjem: usvajanje kognitivnih znanja i vještina, usvajanje psihomotoričkih i komunikacijskih vještina i pozitivnih stavova. 
Kako suvremeno shvaćanje učinkovitog učenja uzima u obzir činjenicu da mnoge varijable utječu na akademski uspjeh, Connolly i sur. (2008) su predložili širi model evaluacije edukativnih igara koji, osim nadziranja uspjeha igrača, uključuje i motivacijske varijable (interes i predanost) i osobna opažanja i stavove.

Stav je autora da analiza utjecaja digitalnih igara na učenike mora uzeti u obzir afektivne/motivacijske faktore i utjecaj na stil učenja ili profil višestrukih inteligencija, uz evaluaciju utjecaja igara na znanje i vještine učenika.

\section{Modeli stilova učenja}

Koncept stilova učenja temelji se na ideji da učenici imaju različite stavove prema učenju pa mu pristupaju na drugačije načine. Određeno okruženje u kojem se odvija nastavni proces možda ne odgovara svim učenicima (Reigeluth, 1996). Na primjer, nekim učenicima više odgovara žustra grupna rasprava, a drugi više vole čitati samostalno. Takve razlike obično se nazivaju stilovima učenja, a stručnjaci ih neprestano prepoznaju, klasificiraju i artikuliraju kako bi postigli pozitivan utjecaj na proces učenja. Različiti stilovi učenja mogu se promatrati kao posljedica različitih načina obrade informacija (Felder, 1996), jer učenici učinkovitije uče ako je nastava organizirana u skladu s njihovim individualnim stilom učenja (Rasmussen i Davidson-Shivers, 1998).

Istraživanja različitih stilova učenja potvrdila su da učenici uče na mnoge načine (Murphy, 1992; Spalter i sur., 2000). Ta je činjenica od presudne važnosti za uključivanje svih učenika u nastavni proces, pogotovo onih čiji je akademski uspjeh ispod prosjeka i onih bez kontinuiranog formalnog obrazovanja. Chorianopoulos i suradnici (2014) tvrde da je igranje videoigara za učenike predstavljalo „mentalnu vježbu" i da je struktura aktivnosti uključenih u videoigre razvila kod učenika kognitivne sposobnosti koje dalje naglašavaju potrebu izrade smislenih i zabavnih aplikacija. Štoviše, dolazak ozbiljnih igara omogućio je sve veće prihvaćanje modela učenja usmjerenog na učenika, kao i druge prilagodbe nastavne prakse.

Park i suradnici (2012) smatraju da teorije Piageta (1976) i Kolba (2014) opisuju proces učenja tijekom četiri faze kognitivnog razvoja i mehanizama učenja koji su neophodni za potpuno razumijevanje i primjenu pojmova. Obojica podržavaju pojam iskustvenog učenja i smatraju da su učenici aktivni istraživači znanja. Prema Shardi (2007), stil učenja je konzistentan model usvajanja i asimilacije informacija od učenika kako bi stekli znanje. Kako su stilovi učenja tijesno povezani s tipovima osobnosti, tijekom godina su izrađeni mnogobrojni modeli za njihovo opisivanje i klasifikaciju, a neke od najpoznatijih izradili su Jung (2014), Myers i Myers (2010), Kolb i suradnici (2014). Iako postoje mnogi modeli, vjerojatno su najčešće spomenuti upravo ovi:

- Model koji su izradili Dunn i Dunn (1978), a koji opisuje pet komponenti podražaja i elemente koji utječu na proces učenja:

o one koji dolaze iz okoline (zvuk, svjetlost, temperatura, dizajn)

o emocionalne (motivacija, odgovornost, ustrajanje u rješavanju zadataka, struktura) 
o sociološke (samostalnost, rad u paru, vršnjaci, tim, odrasle osobe, raznolikost)

o fiziološke (perceptivnost, upijanje, mobilnost, doba dana) i

o psihološke (analitičnost - globalnost, reflektivnost - impulzivnost);

- Teorija Feldera i Silvermana (1988) koja svrstava učenike u četiri kategorije:

o aktivne (vole rasprave, primjenu, objašnjenja) / reflektivne (tiho razmišljaju)

o osjetilne (uče činjenice) / intuitivne (otkrivaju mogućnosti i veze)

o vizualne (vide slike, dijagrame, dijagrame toka itd.) / verbalne (prate pisanu i usmenu riječ) $\mathrm{i}$

o sekvencijalne (razumijevaju preko linearnih koraka) / globalne (uče velikim koracima);

- Kolbova teorija koja navodi četiri stila učenja utemeljena na stupnjevima

o angažiranosti učenika:

o divergentan (osjećanje i gledanje)

o asimilirajući (razmišljanje i gledanje)

o konvergentan (razmišljanje i djelovanje) i

o akomodirajući (osjećanje i djelovanje);

- Honeyev i Mumfordov model (2000) koji dijeli studente u skupine s obzirom na četiri stila:

o reflektor (promatra i refleksivno razmišlja)

o teoretičar (razumije sve razloge u pozadini, pojmove i veze)

o pragmatist (voli isprobavati stvari kako bi vidio funkcioniraju li) i

o aktivist (voli djelovati i iskusiti), i

- Flemingov (2006) VARK model koji razlikuje četiri stila učenja:

o vizualni (više se vole koristiti dijagramima, tablicama i simbolima)

o auditivni (najbolje razumiju nove sadržaje putem slušanja i govorenja)

o čitanje i pisanje (najbolje uče posredstvom riječi)

o kinestetički (najbolje uče preko praktičnog rada, taktilnih aktivnosti).

Različitosti stilova učenja potvrđene su u mnogim studijama, vodeći prema potrebi da se usvoje različiti nastavni procesi (Chwif i Baretto, 2003). Trebalo bi naglasiti da se stilovi učenja mladih „virtualnih” generacija razlikuju od onih prijašnjih generacija, jer su puno više orijentirani na vizualno prezentirane informacije, interakciju i rješavanje problema (Pasin i Giroux, 2011; Proserpio i Gioia, 2007).

Kognitivna procjena može se provesti na različite načine. Prepoznavanje i evaluacija stilova učenja istraživala se stoljećima, primjenom različitih modela i popisa (Weaver i sur., 2013). Psihometrija je znanstveno područje koje se bavi izradom i evaluacijom valjanih psiholoških testova (Hoffman, 2002). Stručnjaci su naglasili tri osnovna problema u izradi instrumenata: nepreciznost definiranja stila učenja, problemi s pouzdanošću i valjanosti, otežano prepoznavanje važnih karakteristika okruženja u kojem se odvija nastavni proces. U kontekstu digitalnih igara učinkovita strategija kod većine stilova učenja jest praktično i aktivno učenje (Bailey i Forbes, 2005; Qiu i Riesbeck, 2004; Roschelle i sur., 2007). 
Trebalo bi spomenuti da se teorijama o stilovima učenja suprotstavila mala skupina istraživača. Na primjer, Felder (1993) je zaključio da su vizualni prikazi adekvatno pomagalo u procesu učenja za učenike kojima više odgovara vizualni stil učenja. Međutim, Grissom i suradnici (2003) nisu prihvatili taj model jer nisu uspjeli dokazati korelaciju između odgovora na vizualne podražaje i prepoznatog vizualnog stila učenja, iako je intuitivno očekuju te navode da bi neki odgovarajući alternativni modeli prepoznavanja stilova učenja vjerojatno doveli do povoljnijih rezultata.

Važno je naglasiti da stilovi učenja ne predstavljaju statičnu osobinu. Učenicima više odgovaraju različiti stilovi učenja, ovisno o kontekstu i motivaciji.

\section{Teorija višestrukih inteligencija}

Gardnerova teorija višestrukih inteligencija (Gardner, 1993) smatra se jednim od ključnih otkrića psihologije odgoja i obrazovanja kasnog dvadesetog stoljeća. Gardner definira inteligenciju kao sposobnost pojedinca da uspješno odgovori na zahtjeve koje postavlja neka nova situacija ili događaj i njegovu sposobnost da uči iz prijašnjih iskustava. Teorija višestrukih inteligencija temelji se na evolucijskog biologiji, neuroznanosti, psihometriji i istraživanjima u području psihologije.

Zahvaljujući svojem individualiziranom pristupu i praktičnoj primjeni u nastavi, teorija višestrukih inteligencija izazvala je entuzijazam u raznim obrazovnim krugovima. Istraživači su ubrzo uočili prednosti prepoznavanja inteligencija u mnogobrojnim područjima, za razliku od prije općeprihvaćenog kvocijenta inteligencije.

Profili inteligencija i njihov opis prema teoriji višestrukih inteligencija (Gardner, 1993) su sljedeći:

- Verbalna/lingvistička - predstavlja primarno sredstvo komunikacije između ljudi. Odražava se u simboličkom razmišljanju, jeziku, čitanju, pisanju;

- Logička/matematička - koristi se za obradu podataka, prepoznavanje uzoraka, rad s brojevima i geometrijskim oblicima;

- Vizualna/prostorna - snalaženje u prostoru, izrada karata, likovna umjetnost, arhitektura, perspektiva;

- Tjelesna/kinestetička - odražava se u preciznoj kontroli pokreta vlastitog tijela, neverbalnom izražavanju emocija, plesu, finoj koordinaciji oka i ruke;

- Glazbena/ritmička - prepoznavanje i korištenje ritmičkih i zvučnih uzoraka, prepoznavanje zvuka, govora i glazbenih instrumenata. Koristi se u interpretaciji i stvaranju glazbe;

- Prirodoslovna - prepoznavanje uzoraka u prirodi, klasificiranje vrsta i oblika biljnog i životinjskog svijeta;

- Interpersonalna - sposobnost surađivanja u malim skupinama, komunikacija s drugim ljudima, sposobnost prepoznavanja namjera, raspoloženja, motivacije i neverbalnih znakova drugih ljudi; 
- Intrapersonalna - prepoznavanje vlastitih sposobnosti, mogućnosti, osjećaja i emocionalnih reakcija, samorefleksija i intuicija.

Dokazi za postojanje devete (egzistencijalne) inteligencije još nisu jasno objašnjeni (Moran i sur., 2006), pa se ona ovdje neće razmatrati.

Teorija višestrukih inteligencija olakšava razumijevanje različitih načina razmišljanja učenika i pomaže nam da ga bolje iskoristimo s ciljem povećanja učinkovitosti učenja, kao i razumijemo i poštujemo individualne razlike među učenicima. Također nam služi i kao dijagnostičko sredstvo za usmjeravanje daljnjeg obrazovanja (Booth i O’Brien, 2008). Računala, digitalna tehnologija i igre u razredu stvaraju prirodno okruženje za praktičnu primjenu teorije višestrukih inteligencija i za prilagodbu nastavne prakse učenju usmjerenom na učenika. Razvoj računalnih programa i doba digitalnih medija učinili su operacionalizaciju individualiziranog učenja praktičnijom, a uključivanje računala i digitalnih igara u okruženje za učenje stvorili su potencijal za daljnji napredak nastavnog procesa aktiviranjem višestrukih inteligencija.

Profil višestrukih inteligencija može procijeniti osobne intelektualne predispozicije učenika. Poteškoće u mjerenju stavova, vještina i karakternih osobina proizlaze iz kompliciranog postupka za kvantificiranje tih istih kvaliteta kako bi se provela analiza podataka. Alate za određivanje profila višestrukih inteligencija izradilo je nekoliko istraživača (Armstrong, 2000; Kagan i Kagan, 1998; Silver i sur. 2000). Inteligencije se mogu procjenjivati s pomoću portfolija, pisanih izvješća, testova, samoevaluacije, uspješnosti u radu na projektima itd. Međutim, iako tradicionalni testovi (papir i olovka) očigledno intenziviraju verbalnu/lingvističku i logičku/ matematičku inteligenciju, opće je istraživačko stajalište da trenutno nije moguće izraditi jedinstvenu alternativnu metodu za evaluaciju višestrukih inteligencija. Obrazovna zajednica ističe Shearerove (2004) Skale za procjenu razvoja višestrukih inteligencija kao najkvalitetniji instrument. Izrađen tijekom protekla dva desetljeća taj je instrument neprestano dorađivan u kombinaciji racionalne i empirijske metodologije te se pokazao valjanim i vrlo pouzdanim. Skala procjenjuje uspješnost višestrukih inteligencija putem samoprepoznavanja vlastitih sposobnosti i težnji.

\section{Istraživanje utjecaja digitalnih igara na stilove učenja i višestruke inteligencije}

Pregled literature osmišljen je s ciljem prikupljanja, klasificiranja i analize rezultata empirijskih istraživanja usmjerenih na veze između digitalnih igara i stilova učenja ili višestrukih inteligencija, kako bi se empirijski mogao potvrditi optimizam zbog potencijalne specifične primjene digitalnih igara u obrazovnom procesu. Analiza se temelji na metodologiji i rezultatima prijašnjih sličnih istraživanja u području primjene ozbiljnih igara, gotovih komercijalnih igara i igara posebno izrađenih za obrazovne svrhe u nastavnom procesu (Connolly i sur., 2008, 2012; Kirriemuir i McFarlane, 2004; Wu i Wang, 2012). S ciljem pregleda literature izrađen je višedimenzionalni okvir za kategorizaciju i primjenu digitalnih igara. 


\section{Metodologija}

Analiza prijašnjih empirijskih istraživanja provedena je na brojnim specifičnim koracima koji su izrađeni na temelju metodologije sustavnog pregledavanja literature (Higgins i Green, 2008; Khan i sur., 2001):

- izrada protokola pregledavanja literature

- prikupljanje podataka

- određivanje kriterija za odabir

- odabir podataka

- analiza podataka (kategorizacija i kvalitativna analiza)

- evaluacija/zaključak.

\section{Izrada protokola i prikupljanje podataka}

Izrađen je protokol za pregledavanje literature u skladu sa smjernicama i postupcima Campbellova sustavnog pregledavanja literature (Petticrew i Roberts, 2000) i Cochraneovim Priručnikom za sustavno pregledavanje literature i intervencije (Higgins i Green, 2008). Razmatrajući te postupke, odredili smo cilj istraživanja, strategije pretraživanja i prikupljanja podataka, kriterije odabira i metode analize.

Kako bismo proveli istraživanje, prikupljanje podataka završeno je u srpnju 2015. godine. Analiza je provedena na uzorku radova prikupljenih iz 11 dostupnih elektroničkih baza podataka koje su relevantne za područja obrazovanja, informacijskih tehnologija, računalnih znanosti i drugih znanosti: ACM Digital Library (http://dl.acm.org/), Cambridge Journals Online (http://journals.cambridge. org/), Elsevier/ScienceDirect (http://www.sciencedirect.com/), ERIC (http://eric. ed.gov/), Oxford Journals (http://www.oxfordjournals.org/en/), Emerald (http://www. emeraldinsight.com/), IEEE Xplore Digital Library (http://ieeexplore.ieee.org/Xplore/), Wiley Online Library (http://onlinelibrary.wiley.com/), Springer/Kluwer (http://link. springer.com/), Sage Journals (http://online.sagepub.com/), IngentaConnect (http:// www.ingentaconnect.com/).

Kriteriji odabira repozitorija (elektroničke baze podataka) bili su ograničeni dostupnošću kompletnih radova u tim bazama.

\section{Kriteriji prepoznavanja i odabir radova}

U skladu s interesnim područjem koristili smo se sljedećim terminima: "game", "learning style" i"multiple intelligences". Rezultati dobiveni upitom dalje su filtrirani s ciljem usmjeravanja na utjecaj digitalnih igara u obrazovanju, jer smo uzeli u obzir radove koji su sadržavali samo ove termine: „digital”,,,video”, „game-based”, „serious”, „MMO”, „,commercial”, „COTS”, „online”, voutcome”, ,skill”, ,,evaluation”, ,impact”, „effect", ,education”, , ,behaviour", , ,attitude”, ,,engagement”, ,, motivation” $i$, ,affect”.

Termini povezani s utjecajem digitalnih igara (video, ozbiljne, komercijalne, online, obrazovanje itd.) na stilove učenja ili višestruke inteligencije uzeti su nakon razmatranja termina koji se koriste za ishode, utjecaj, učinak, vještine, ponašanje, motivaciju, stavove i dojmove: 
(game OR "learning style" OR "multiple intelligences") AND (digital OR video OR serious OR commercial OR online OR education OR MMO OR COTS) AND ("gamebased" OR outcome OR skill OR evaluation OR impact OR effect OR behavior OR attitude OR engagement OR motivation OR affect)

Kako bi se rad uopće mogao razmatrati u analizi, morao je ispuniti određene kvalitativne kriterije:

- u njemu se moralo raditi o istraživanju utjecaja digitalnih igara na stilove učenja ili višestruke inteligencije

- morao je biti objavljen u posljednjih 15 godina (od siječnja 2000. do lipnja 2015.)

- mogao se s interneta skinuti kao potpuni tekst i morao je sadržavati sažetak

- napisan je na engleskom jeziku.

Primjenom tih kriterija prepoznato je i za daljnju analizu odabrano 5740 radova.

\section{Analiza podataka}

Kako bi se osigurala kvaliteta primjene kriterija na odabrani uzorak, izrađena je tipologija prema priznatoj, prihvaćenoj i uspješno primjenjivanoj shemi (Dempsey i sur., 1993, 1996; Wu i Wang, 2012). Tipologija je prilagođena kako bi se rezultati mogli usustaviti i kako bi se dalje moglo raspravljati o vezama između digitalnih igara i stilova učenja ili višestrukih inteligencija. Stoga smo definirali pet tipova radova:

- istraživanje (sustavno empirijsko ispitivanje utjecaja digitalnih igara s ciljem objašnjavanja, predviđanja ili kontroliranja određenih fenomena i varijabli vezanih uz stilove učenja ili višestruke inteligencije);

- teorijski prikaz (objašnjenje osnovnih pojmova, aspekata ili indirektnih ishoda korištenja digitalnih igara u obrazovanju);

- pregledni rad (sinteza radova prema definiranoj metodologiji koji općenito ili specifično ispituju veze između digitalnih igara i stilova učenja ili višestrukih inteligencija);

- rasprava (esej u kojemu se iznosi iskustvo ili stav bez empirijskih dokaza);

- rad u kojem se prikazuje razvojni projekt (dizajn ili razvoj digitalnih igara ili projekata u skladu sa stilovima učenja ili inteligencijama).

Autori su najprije pregledali i procijenili dobivene naslove i sažetke prema kriteriju važnosti. Odabrani radovi dalje su neovisno evaluirani kako bi se smanjio subjektivni utjecaj. Kategorizacija odabranih radova provedena je na temelju nekoliko kriterija:

- vrsta rada: istraživanje, teorijski prikaz, pregledni rad, rasprava, rad u kojem se prikazuje razvojni projekt;

- primarna paradigma računalne igre: gotova komercijalna igra, edukativna, primijenjena, masivna mrežna online igra uloga;

- žanr (prema proširenoj Herzovoj sistematizaciji);

- područje primjene: opće, u znanosti, inženjerstvu, matematici, jezicima, zdravstvu, povijesti; 
- platforma: računalo, igraća konzola, mobilni telefon, online;

- veza sa stilom učenja ili višestrukim inteligencijama;

- oblik empirijskog istraživanja: deskriptivno (anketa, analiza slučaja), korelacijsko (istraživanje parova), kvazieksperimentalno, eksperimentalno, pregled literature, metaanaliza;

- empirijska veličina uzorka;

- prikupljanje i analiza empirijskih podataka: ciljevi istraživanja, metodologija, rezultati;

- reference.

Kako bi se dodatno procijenili radovi, provedena je kvalitativna analiza četiriju definiranih kategorija te je dobiven raspon ocjena od 1 do 10. Kategorije parcijalne ocjene su:

- Tip istraživanja:

- 1 - deskriptivno (teorija, rasprava, razvojni projekt )

o 2 - korelacijsko (pregledni rad)

o 3 - kvazi-eksperimentalno

o 4 - eksperimentalno

o 5 - pregled literature, metaanaliza;

- Adekvatna metodologija i analiza (0 - ne, 1 - da)

- Kvaliteta uzorka - reprezentativnost (0 - niska, 1 - srednja, 2 - visoka)

- Relevantnost za ovo istraživanje (0 - niska, 1 - srednja, 2 - visoka).

Kako je jedan od autora stručnjak za metodologiju pisanja preglednih radova, $\mathrm{u}$ samo dva slučaja nejasne/problematične procjene rada morala su se konzultirati dva renomirana stručnjaka u području psihologije odgoja i obrazovanja.

\section{Rezultati}

Tendencija porasta broja radova objavljenih s obzirom na godinu i repozitorij može se vidjeti u prikazu 2. Reprezentativna struktura rezultat je primjene kvalitativnih kriterija. Očigledno povećan interes istraživača tijekom posljednjih deset godina pokazuje da je to pitanje vrlo aktualno. Jedan od razloga za takvu tendenciju svakako je dolazak učenika koji odrastaju u kulturi prožetoj digitalnim igrama u kojoj se fokus s potencijalno negativnog utjecaja digitalnih igara prebacio na pozitivne utjecaje, kao što su društvena integracija, poboljšanje različitih vještina i povećano korištenje igara u obrazovanju. Također, trebalo bi imati na umu da su mlađi nastavnici odrasli u sličnom kulturnom miljeu, pa je upotreba digitalnih igara u nastavnom procesu njima potpuno normalna. Stav autora je da bi taj fenomen trebalo interpretirati kao još jedan oblik utjecaja digitalnih igara na stilove učenja učenika, njihove inteligencije, a indirektno i na nastavnu praksu.

Prikaz 2 
Pregled broja radova odabranih iz definiranih repozitorija prikazan je u tablici 1. Kao što se može primijetiti, $74 \%$ uzorka bilo je prvobitno pohranjeno u sljedeća tri repozitorija: Elsevier/ScienceDirect $(\mathrm{N}=1653)$, Wiley Online Library $(\mathrm{N}=1650)$ i Springer/Kluwer $(\mathrm{N}=918)$.

Pretragom po upitima 11 dostupnih repozitorija, ukupno je odabrano 5740 radova, $\mathrm{u}$ skladu s definiranim kriterijima. Na primjer, prilično čest razlog neprihvaćanja radova bio je da su predmet njihova proučavanja teorija igranja ili ekonomija.

Kategorizacija i primjena definiranih kvalitativnih kriterija smanjila je uzorak na 36 radova. Odbačeni radovi često nisu ispitivali utjecaj digitalnih igara, nego tjelesne igre i aktivnosti. Posteri, prezentacije i tutorijali također su često bili odbačeni jer nisu davali detaljan opis istraživanja, što je praktički onemogućilo evaluaciju metodologije ili rezultata.

\section{Tablica 1}

Svaki rad koji je odgovarao određenim kvalitativnim kriterijima dodatno je procijenjen putem kvalitativne analize. Radovi su najprije bili grupirani u pet definiranih tipova: istraživanje $(\mathrm{N}=19)$, teorijski prikaz $(\mathrm{N}=4)$, pregledni rad $(\mathrm{N}=2)$, rasprava $(\mathrm{N}=4)$, rad u kojem se prikazuje razvojni projekt $(\mathrm{N}=7)$. $\mathrm{U}$ skladu s rezultatima sličnih analiza (Hays, 2005) broj radova u kategorijama pregledni rad, rasprava i teorijski prikaz bio je malen, što se može objasniti činjenicom da je primjena digitalnih igara u obrazovanju još uvijek relativno nova domena obrazovne prakse.

Distribucija ocjena dobivena kvalitativnom analizom prikazana je u tablici $3 \mathrm{i}$ prikazu 3. Srednja vrijednost ocjene za odabranih 36 radova je 5,44 (standardna devijacija $=2,466$ ), a ocjena modela je 5 , što ukazuje na činjenicu da se radovi koji su ocijenjeni ocjenom 5 ili višom ocjenom smatraju metodološki relevantnijim i u ovom slučaju pružaju ,jače” dokaze.

\section{Tablica 2}

\section{Prikaz 3}

Rezultati strukturne analize reprezentativnog uzorka prikazani su u tablici 3. Većina radova prikazala je istraživanja o primjeni edukativnih igara (66,7\%), primjena ozbiljnih igara ispitivala se u pet radova (13,9\%), gotove komercijalne igre bile su tema četiri rada $(11,1 \%)$, a primjena masivne mrežne online igre uloga bila je analizirana u tri rada. Radovi koji su ispitivali žanrove igara, slagalice, simulacije i igre uloga bili su najbrojniji (58,3\%). Najčešće edukativne igre bile su slagalice (25\%), igre uloga $(20,8 \%)$ i simulacije $(12,5 \%)$.

\section{Tablica 3}

Istraživači su uglavnom igrali igre na računalnoj platformi $(80,6 \%)$ s općom/ univerzalnom svrhom (58,3\%), često za simulacije ili slagalice(47,1\%). Radovi su najčešće ispitivali stilove učenja, uglavnom za opću primjenu $(55,2 \%)$, a u $13,9 \%$ radova istraživao se utjecaj igara na višestruke inteligencije. Struktura primjene igara u odabranim radovima prikazana je u t 4 . 


\section{Tablica 4}

Glavni cilj ovog rada jest prikazati i analizirati istraživanja o utjecaju digitalnih igara na stilove učenja i višestruke inteligencije. Broj radova koji se bavi tim temama, a koji su zadovoljili stroge kriterije, očito je vrlo malen. Eksperimentalna istraživanja $i$ analize slučaja bile su najčešće metode (50\%). Velik broj radova o utjecaju digitalnih igara koji nisu odgovarali uvjetima za analizu bio je fokusiran na motivaciju, kognitivna postignuća $i$ ishode.

\section{Rasprava}

Sistematičan pregled usmjeren je na analizu istraživanja o vezi između digitalnih igara i stilova učenja ili višestrukih inteligencija. Upiti koji su se koristili za pretraživanje repozitorija otkrili su velik broj radova $\mathrm{u}$ kojima se istražuje upotreba igara $\mathrm{u}$ obrazovanju. Daljnja analiza potvrdila je stav autora da je interes za ispitivanje utjecaja digitalnih igara na učenike (i učenje općenito) u posljednjem desetljeću porastao. Međutim, radovi su uglavnom prikazivali teorijska razmatranja i rasprave o upotrebi igara koje nisu bile povezane sa stilovima učenja ili višestrukim inteligencijama, niti su imale uporište u odgovarajućim empirijskim dokazima, pa su stoga isključene iz analize. Analiza provedena primjenom kriterija otkrila je 36 radova, čime je potvrđena sumnja u postojanje malog broja empirijskih dokaza. Reprezentativni radovi varirali su s obzirom na ciljeve istraživanja, teorijski okvir i metodologiju, što je posljedica interdisciplinarnosti i interesa raznih autora za proučavanje digitalnih igara.

Kako se pokazalo da metaanaliza nije odgovarajuća metoda zbog raznolikih uzoraka, okružja i metodologije istraživanja, pregled je napisan u narativnom obliku.

Razvoj digitalnih igara i analiza utjecaja stilova učenja prikazani su u sedam odabranih radova. Hwang i suradnici (2015) izradili su igru uloga kako bi procijenili postignuća i motivaciju primjenom kvazieksperimenta na uzorku od 87 dvanaestogodišnjih učenika osnovne škole na Tajvanu. Zaključili su da je 48 učenika iz eksperimentalne skupine postiglo znatno bolje rezultate i da su bili pozitivno motivirani zbog kontekstualnog pristupa koji se koristio igrama namijenjenim za obrazovne svrhe i aktivni stil učenja. Rezultat je u skladu sa stavom Leeja i Butlera (2003) da su autentične aktivnosti osnova za rješavanje problemskih situacija. Erhel i Jamet (2013) istaknuli su da za vrijeme igranja kontekstualne edukativne računalne igre učenici čiji je stil učenja uglavnom aktivan ostvaruju bolje rezultate od onih čiji je stil učenja uglavnom reflektivan. Boctor (2013) se koristio strategijom aktivnog učenja i osmislio igru asocijacije „Nursopardy” za učenike srednje medicinske škole, kako bi procijenio njezinu učinkovitost u nastavi. Najprije su kod 39 učenika ispitani stilovi učenja, a tada je nacrt igre prilagođen dobivenim rezultatima. Nakon što su učenici odigrali igru, ispitani su njihovi stavovi. Većina ih je smatrala da je igra korisna za usvajanje novog znanja i kao dodatni nastavni materijal. Soflano i suradnici (2015a) izradili su prilagodljivu igru uloga za učenje strukturiranog upitnog jezika (SQL) utemeljenu na Felder-Silvermanovu (1988) modelu stilova učenja. Uzorak 
u istraživanju sastojao se od 120 učenika. Rezultati su pokazali da igre izrađene za obrazovne svrhe povećavaju stupanj motivacije i postignuća učenika, ali nije utvrđen utjecaj na učinkovitost igranja povezan sa stilom učenja. Giles (2015) je izradio igru „Misterij u knjižnici” u skladu sa stilovima učenja i s namjerom upoznavanja studenata strojarstva s potencijalom sveučilišne knjižnice. Intervjuirana su 44 studenta te je zaključeno da su studenti pozitivno reagirali na igru i da su bili pozitivno motivirani. Leach i Sugarman (2005) također su pokazali pozitivan utjecaj edukativnih igara u stilu igre „Jeopardy” na nastavu u knjižnici i na motivaciju. Igru su izradili na Državnom sveučilištu u Georgiji. Hwang i suradnici (2012) izradili su individualiziranu igru uloga na osnovi rezultata dobivenih primjenom upitnika izrađenog prema FelderSilvermanovu modelu stilova učenja (1988). Skupina od 46 učenika osnovne škole sudjelovala je $\mathrm{u}$ istraživanju u sklopu nastave prirodoslovnih predmeta. Zaključeno je da su učenici koji su igrali igre prilagođene svojem stilu učenja pokazali znatno bolja postignuća i pozitivnu motivaciju. Cheng i Chen (2008) koristili su se online platformom za učenje kao podrškom pri učenju prirodoslovnih predmeta u osnovnoj školi. Istraživanje je provedeno kao kvazieksperiment $s$ dva peta razreda. Rezultati nisu pokazali značajnu prednost korištenja online edukativnih igara, ali su učenici i roditelji pokazali pozitivan stav i povjerenje u takav sustav obrazovanja.

Reprezentativni radovi ocijenjeni visokim ocjenama koji su prezentirali razvoj i izradu igara u vezi sa stilovima učenja bili su objavljeni u posljednje tri godine, što se može objasniti kao znak zrelosti i jasne i prihvaćene teorijske osnove. Stoga istraživači postupno počinju praktično provoditi prije ograničene eksperimentalne spoznaje.

Istraživanja o utjecaju digitalnih igara na stilove učenja prikazana su u 19 odabranih reprezentativnih radova. Chwif i Barretto (2003) izradili su taksonomiju za igre u operacijskom menadžmentu i prikazali modele praktične primjene u skladu sa stilovima učenja učenika. Zaključili su da je izrađeni didaktički model simulacije učinkovita nastavna tehnika. Ahmet i suradnici (2011) ispitali su mogućnosti upotrebe Nintendo Wii senzora u kombinaciji s videoigrama kako bi izradili alate za proučavanje osnovnih pojmova u fizici. Stilovi učenja 18 učenika švedske osnovne škole ispitani su primjenom upitnika izrađenog po modelu Dunna i Dunna (1978). Izrada interaktivnog digitalnog okruženja bila je uspješna i poboljšala je suradnju među učenicima te učinila učenje zanimljivijim i zabavnijim. Sylvén i Sundqvist (2012) ispitivali su vezu između igranja računalnih igara i učenja engleskog jezika na uzorku od 86 učenika švedske osnovne škole u dobi od 11 do 12 godina. Primijetili su izravnu korelaciju između vremena koje su učenici proveli igrajući i rezultata ostvarenog na testu iz engleskog jezika, kao i to da su dječaci imali bolje rezultate od djevojčica. Feldman i suradnici (2014) upotrebljavali su igru „Equilibrium” kako bi procijenili usvajanje apstraktnih pojmova i kreativno rješavanje složenih problema. Zaključili su da se perceptivni stil mogao uspješno odrediti s pomoću računalne igre „Equilibrium” i upitnika izrađenog prema Indeksu stilova učenja na uzorku od 63 studenta računalne znanosti, s preciznošću od $85,1 \%$. Soflano i 
suradnici (2015b) su na uzorku od 60 učenika uočili prilagodbu stila učenja za vrijeme igranja edukativne računalne igre. Prije eksperimenta sudionici su ispunili upitnik izrađen prema Felder-Silvermanovu modelu stilova učenja (1988) kako bi se utvrdio prevladavajući stil učenja, a tijekom igranja analizirala se interakcija s igrom kako bi se ponovno provelo utvrđivanje stila učenja. Istraživanje je pokazalo da se stil učenja prilagođava tijekom igranja igrice ako to znači da će se cilj brže ostvariti. Snyder i suradnici (2009) proveli su analizu nastave s pomoću simulacije virtualne stvarnosti na 36 studenata medicine te zaključili da simulacija nije pokazala statistički značajne prednosti u usporedbi s tradicionalnim nastavnim metodama. Malekian i suradnici (2012) ispitivali su utjecaj edukativnih igara na prostornu inteligenciju primjenom kvazieksperimenata na uzorku od 40 srednjoškolaca, te dokazali postojanje korelacije između prostorne inteligencije i komplementarnih edukativnih prikaza. Lynch i suradnici (2008) ispitivali su utjecaj igara koje se igraju na web-pregledniku na stilove učenja i postignuća na uzorku od 300 učenika u SAD-u. Zaključili su da rezultati eksperimenta nisu pokazali statistički značajnu korelaciju između igranja igara i stilova učenja. Bekebrede i suradnici (2011) istraživali su utjecaj igranja 23 digitalne igre na uzorku od 1607 učenika u Nizozemskoj i potvrdili postojanje veze između stila učenja i igranja igre, uglavnom putem promicanja aktivnog i suradničkog učenja. Corbeil i Laveault (2008) su procijenili valjanost upotrebe digitalnih igara u nastavi povijesti na uzorku od 65 učenika. Naveli su da je utjecaj igara u prosjeku bio jednako učinkovit kao i tradicionalna predavanja te da su simulacije bile korisnije učenicima kojima je bila potrebna pomoć u razvijanju konkretnog operativnog načina razmišljanja. Zaključili su da je igranje pozitivno motiviralo učenike kojima je više odgovarao senzorno-motorički stil učenja. Arora i Saxena Arora (2015) prikazali su interdisciplinarnu eksperimentalnu igru „SC-Mark” izrađenu za obuku u području marketinga i menadžmenta. U eksperimentu je ukupno sudjelovao 161 student tijekom dva semestra. Pokazalo se da su eksperimentalno igranje igre i simulacije učinkovito okruženje za nastavu i učenje o realističnim situacijama u poslovnom svijetu. Ku i suradnici (2014) izradili su sustav za učenje idioma u kineskom jeziku putem igranja računalnih igara. Na uzorku od 56 osnovnoškolaca na Tajvanu došli su do spoznaje kako su učenici kod kojih je prepoznat aktivan i vizualan stil učenja ostvarili znatno bolje rezultate. Dempsey i suradnici (2002) testirali su utjecaj različitih žanrova igara na uzorku od 40 odraslih ispitanika u dobi između 18 i 52 godine. Uočeno je da simulacije i arkadne igre imaju daleko drugačiji utjecaj na populaciju s obzirom na spol, jer su ispitanice bile manje motivirane za igru i arkadne su igre smatrale agresivnima. $\mathrm{Na}$ temelju Kolbova upitnika (2014) ispitanice su u visokom postotku bile akomodatori i divergatori, a ispitanici su muškog spola uglavnom bili konvergatori i asimilatori. VanDeventer i White (2002) proveli su istraživanje na sedam stručnjaka u igranju videoigara tinejdžerske dobi (10 - 11 godina). Zaključili su da su „napredni” igrači bili jako dobri u aktivnom traženju novih informacija, bolje su procijenili nepoznate situacije, kategorizirali su informacije i pokazali vještine kritičkog mišljenja. Hwang i 
suradnici (2013) istraživali su mišljenja učenika o odabiru najpogodnijeg obrazovnog sustava s obzirom na stilove učenja prema Felder-Silvermanovu modelu. Analizirali su rezultate 288 učenika i zaključili da ne postoje razlike u odabiru edukativnih igara s obzirom na žanr ili stil učenja, ali da se do rezultata obično dolazi intuicijom ili osobnom sklonošću. Kellner i Weißenbacher (2012) integrirali su test o stilovima učenja u edukativnu igru. Na uzorku od 28 adolescenata u dobi od 12 do 13 godina utvrdili su da je moguće provesti takvu integraciju primjenom Vesterova (1991) testa. Hwang i suradnici (2008) ispitivali su utjecaj igranja masivne mrežne online igre uloga „Second Life” (Molka-Danielsen i Deutschmann, 2009) na prostorne percepcije i stil učenja učenika. Uzorak je obuhvatio 73 učenika u Koreji u dobi od 20 do 22 godine. Zaključeno je da je takva aktivnost puno učinkovitija u skupini učenika s apstraktnim konceptualnim stilom.

Reprezentativni radovi koji su se bavili istraživanjem utjecaja digitalnih igara na stilove učenja razlikovali su se s obzirom na metodologiju, model stilova učenja ili žanr igara. Većina odabranih radova $(87,5 \%)$ dokazala je postojanje korelacije između igranja digitalnih igara i stilova učenja.

Primjena digitalnih igara s obzirom na stil učenja ili inteligenciju bila je temom četiriju odabranih radova. Iqbal i suradnici (2010) koristili su se masivnom mrežnom online igrom uloga „Second Life” kao platformom za obrazovanje odraslih u kontekstu učenja jezika. Istaknuli su da je njihov prilagodljiv model učenja bio izrađen u skladu s teorijom višestrukih inteligencija s ciljem premošćivanja razlika između pristupa učenju i tehnologije. Materijali za učenje prikazani su u skladu s profilom višestrukih inteligencija učenika, što je pružilo mnogobrojne mogućnosti za sudjelovanje u neformalnom obrazovanju i poboljšanje iskustva učenja. Gosalia i suradnici (2015) primijenili su igru „MathMazing” utemeljenu na gestikulaciji za učenje aritmetike u osnovnoj školi. Zaključili su da je takva praktična nastava bila učinkovita te je dovela do većeg stupnja zadržanog znanja. Li i suradnici (2012) analizirali su teoriju edukativnih igara i njezinu vezu s višestrukim inteligencijama. Dali su detaljan opis utjecaja edukativnih igara na razvoj logičke/matematičke inteligencije i strategije razvoja inteligencija. U analizi postojeće literature Bennet i suradnici (2008) su pokazali nedostatak empirijskih dokaza da nove generacije učenika i igrači digitalnih igara imaju sofisticirane tehnološke vještine i poseban stil učenja, pa stoga tradicionalni obrazovni sustav ne može na odgovarajući način zadovoljiti potrebe tih učenika.

Tema četiriju radova bila je teorijska podloga primjene digitalnih igara u skladu sa stilovima učenja ili višestrukim inteligencijama. Howard (2005) je predložio strategije za razvoj komunikacijskih vještina i inkluzivnog okruženja, uzimajući u obzir stilove učenja, interaktivne igre i suradničko učenje. Kapp (2007) je razmatrao neformalne metode prijenosa znanja na igrače i njihovu primjenu u organizacijama. Bellotti i suradnici (2010) izradili su vizualne alate s ciljem prezentiranja kvalitetnih kontekstualnih informacija u virtualnom svijetu u skladu sa stilovima učenja, kako bi učenici mogli maksimalno iskoristiti igranje igara. González i suradnici (2007) 
izradili su platformu kako bi povećali stupanj interakcije i društvenu komunikaciju među djecom u kontekstu obrazovanja djece s posebnim potrebama. Koncept se temelji na osobno dizajniranim piktogramima putem kojih djeca mogu povezivati gramatičke strukture sa svojim idejama, istodobno se zabavljajući. Zaključili su da igranje digitalnih igara može pomoći u ostvarenju bolje prostorne koordinacije, koncentracije i motivacije.

Uočena su i dva reprezentativna pregledna rada. Posebno se ističe sustavan prikaz Blakelyja i suradnika (2009), jer su oni proveli analizu istraživanja o primjeni edukativnih igara u zdravstvu od 1980. do 2008. godine. Odabravši 1829 radova, napravili su detaljnu analizu 16 odabranih radova koji su odgovarali kriterijima odabira. Zaključili su da primjena igara može odgovarati pojedinim stilovima učenja, no nisu uspjeli poduprijeti tu tvrdnju adekvatnim empirijskim istraživanjem. Ypsilanti i suradnici (2014) ispitivali su čimbenike igranja ozbiljnih igara kao sredstva neformalnog učenja. Rezultati su pokazali jako malen broj primjera njihove primjene $\mathrm{i}$ istraživanja o učinkovitosti primjene ozbiljnih igara kao nastavne metode.

Pregled odabranih reprezentativnih radova prikazan je u Dodatku. Rezultati analize pokazuju da su se istraživači često koristili analizama slučaja i eksperimenata. Iako se gotove komercijalne igre i masivne mrežne online igre uloga uvelike koriste i učenici obično igraju samo takve igre, iznenađujuće je malen broj radova analizirao njihov utjecaj na učenje ili osobnost. Opći je zaključak da igranje digitalnih igara obično vodi poboljšanju kognitivnih sposobnosti i vještina učenika. Učenici s aktivnim $i$ vizualnim stilom učenja mogu imati veliku korist od igranja digitalnih igara, isto kao i učenici s visoko razvijenom logičkom/matematičkom, vizualno/prostornom ili tjelesno/kinestetičkom inteligencijom. Opazili smo da su istraživanja uglavnom bila usmjerena na računalne igre, obično simulacije i slagalice, vjerojatno zato što njihova upotreba u obrazovanju postoji duže nego ostale platforme. Velika slabost mnogih istraživačkih radova povezana je s dizajnom i primijenjenim metodama, jer uzorci često nisu dovoljno reprezentativni, pa se do opaženih utjecaja igara moglo doći zbog razlika među ispitanicima, a ne zbog intervencije.

\section{Ograničenja}

Sustavan pregled izrađen je s određenim ograničenjima, kao što su termini koji su se koristili u pretraživanju, dostupni repozitoriji i definirani vremenski okvir unutar kojega su radovi objavljeni. Ipak, radovi koji su udovoljili kriterijima i zahtjevima kvalitativne analize mogu se smatrati valjanim uzorkom empirijskih dokaza o utjecaju digitalnih igara na stilove učenja i višestruke inteligencije. Pregled je isključio radove koji su se temeljili samo na teoriji ili nagađanjima.

\section{Zaključci}

Višekriterijska analiza istraživanja o vezi između digitalnih igara i stilova učenja ili višestrukih inteligencija rezultirala je izradom okvira za organizaciju rezultata $i$ 
prepoznavanje pozitivnih utjecaja ili teškoća. Iako je usustavljen pregled literature pružio neke empirijske dokaze, postoji očita potreba za daljnjim istraživanjima. Kvalitativno istraživanje pomoglo bi boljem shvaćanju i prepoznavanju metoda za učinkovitiju primjenu digitalnih igara u obrazovanju, posebno u iskorištavanju potencijala psihologijskih teorija o stilovima učenja i višestrukim inteligencijama.

Kako bi se primijenio model učenja utemeljen na digitalnim igrama kao valjan dodatak modernom obrazovanju, neophodno je kontinuirano procjenjivati njegove oblike i utjecaj na procese i stilove učenja i njihove karakteristike. Iako je pojam višestrukih inteligencija tek započeo svoju transformaciju od teorijskog okvira prema praktičnoj primjeni, mnogi nastavnici već nesvjesno rade u skladu s njim. Uvođenje odgovarajućih digitalnih igara, davanje smjernica učenicima i planiranje aktivnosti prilagođenih stilovima učenja ili višestrukim inteligencijama može im pružiti priliku za bolje i učinkovitije usvajanje novih znanja i vještina.

Iako je sustavan prikaz proširio razumijevanje kategorizacije i prepoznavanja utjecaja digitalnih igara na stilove učenja i inteligencije, postavljaju se i određena pitanja za buduća istraživanja:

- Treba li primjena digitalnih igara u obrazovanju utjecati na stilove učenja ili bi igre trebale biti izrađene u skladu sa stilovima učenja i njima prilagođene?

- Treba li fokus primjene digitalnih igara u skladu s višestrukim inteligencijama biti lakše usvajanje znanja, razvoj perceptualnih/kognitivnih vještina, pozitivni afektivni/motivacijski ishodi ili promjena ponašanja?

Tradicionalni nastavni okvir predstavlja emocionalno, društveno i kognitivno iskustvo u kojem se nastavnici koriste svojim znanjem, glasom ili pokretima kako bi učenicima dali informacije ili im postavili pitanja. Giannakos i Vlamos (2013) naveli su da humor može doprinijeti većoj angažiranosti učenika u nastavnom procesu i atmosferu u razredu čini ugodnom.

Autori ne očekuju (niti predviđaju) da će digitalne igre zamijeniti tradicionalno, mješovito ili učenje na daljinu i e-učenje, nego naglašavaju važnost primjene različitih alata u nastavi i učenju koji ne pripadaju tradicionalnom nastavnom okviru, kako bi ih uspješno povezali sa spektrom stilova učenja i inteligencija. 